DOE/ID-22172

\title{
CHEMICAL AND RADIOCHEMICAL CONSTITUENTS IN WATER FROM WELLS IN THE VICINITY OF THE NAVAL REACTORS FACILITY, IDAHO NATIONAL ENGINEERING AND ENVIRONMENTAL LABORATORY, IDAHO, 1999
}

U.S. GEOLOGICAL SURVEY OPEN-FILE Report 01-27

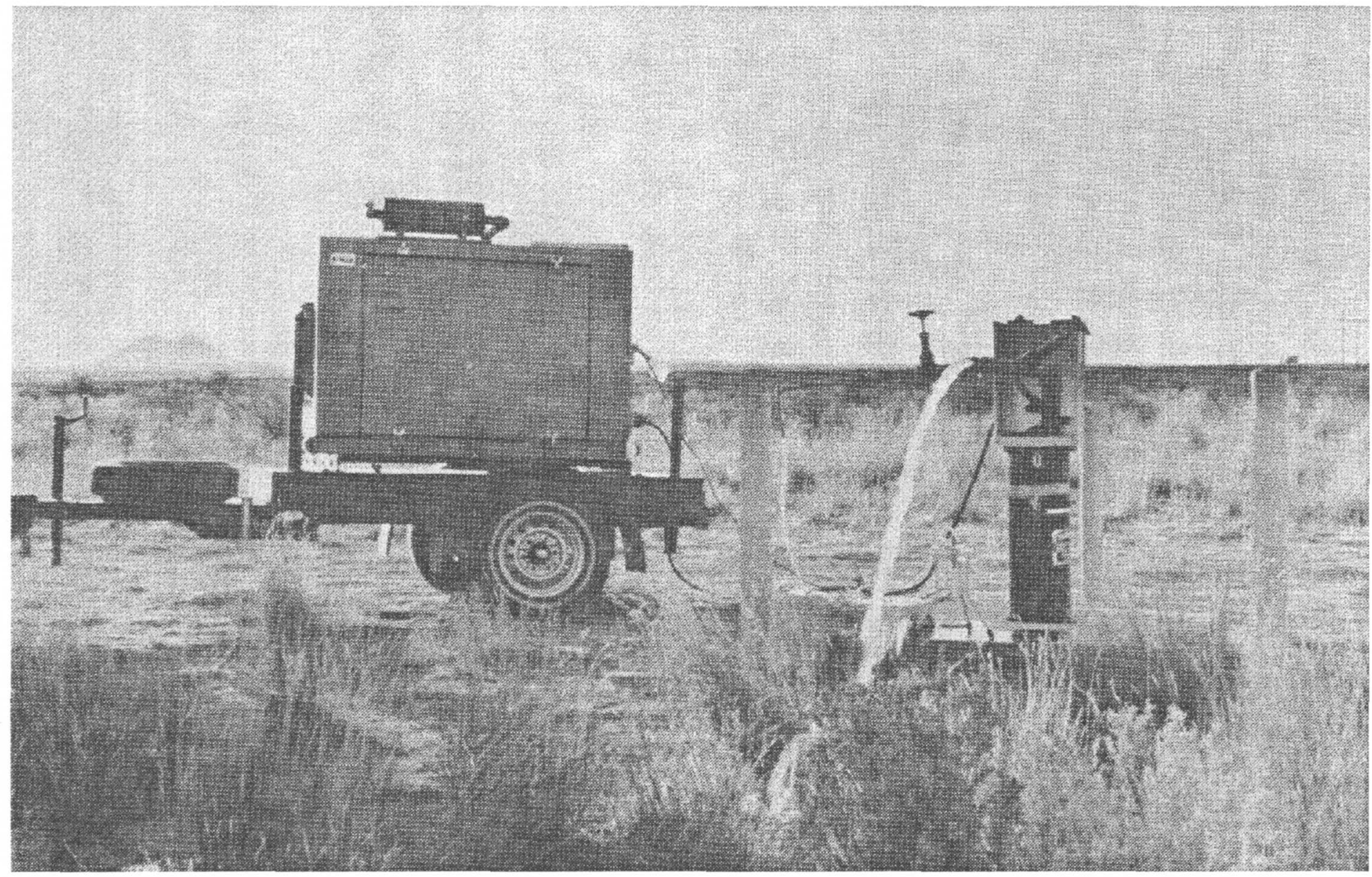

Prepared in cooperation with the U.S. DEPARTMENT OF ENERGY

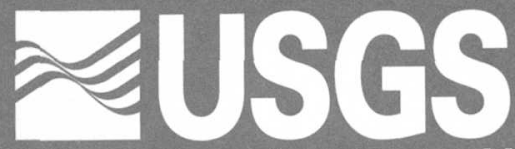


$\because$

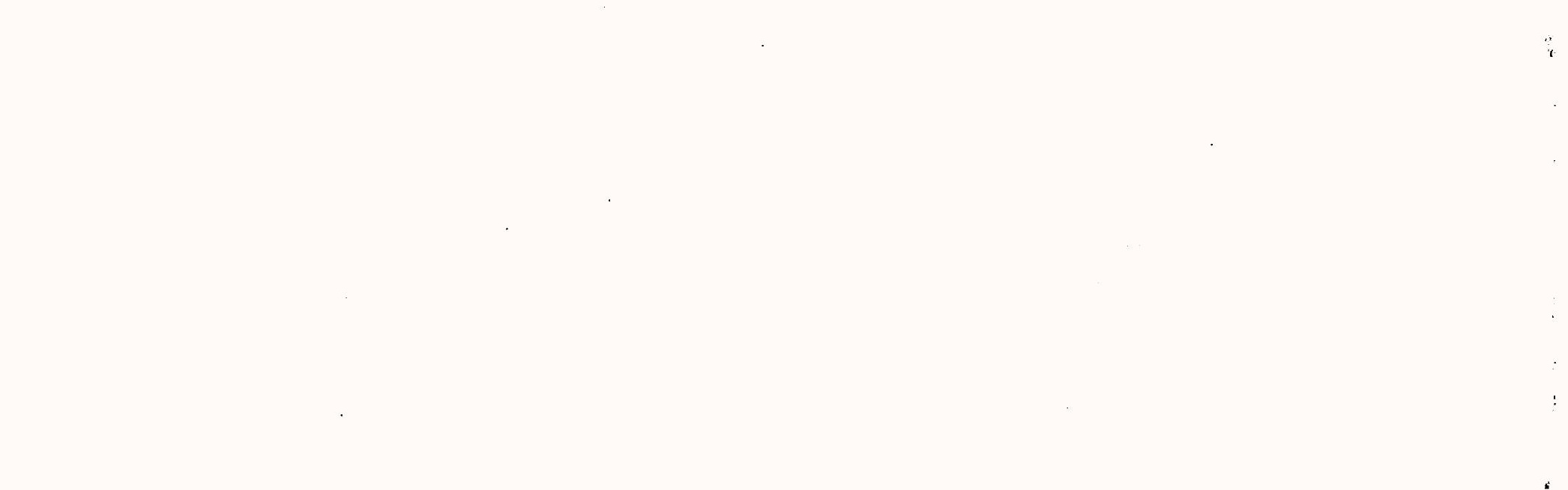<smiles>[H]</smiles>

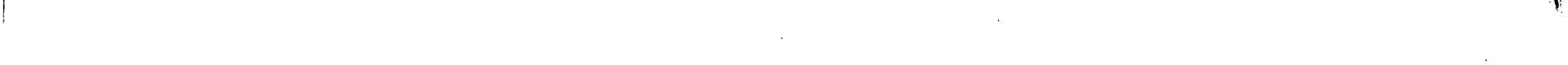

.

.

$7^{\circ}$ 


\section{CHEMICAL AND RADIOCHEMICAL CONSTITUENTS IN WATER FROM WELLS IN THE VICINITY OF THE NAVAL REACTORS FACILITY, IDAHO NATIONAL ENGINEERING AND ENVIRONMENTAL LABORATORY, IDAHO, 1999}

By Roy C. Bartholomay, LeRoy L. Knobel, Betty J. Tucker, and Brian $\mathrm{V}$. Twining

\section{U.S. GEOLOGICAL SURVEY}

Open-File Report 01-27

Prepared in cooperation with the U.S. DEPARTMENT OF ENERGY 


\title{
U.S. DEPARTMENT OF THE INTERIOR \\ GALE A. NORTON, Secretary
}

\author{
U.S. GEOLOGICAL SURVEY \\ CHARLES G. GROAT, Director
}

Any use of trade, product, or firm names in this publication is for descriptive purposes only and does not constitute endorsement by the U.S. Government.

For additional information write to:

U.S. Geological Survey

INEEL, MS 1160

P.O. Box 2230

Idaho Falls, ID 83403
Copies of this report can be purchased from:

U.S. Geological Survey

Information Services

Box 25286, Federal Center

Denver, CO 80225 
CONTENTS

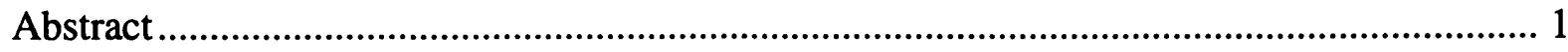

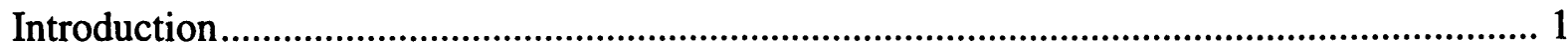

Purpose and scope ........................................................................................... 1

Hydrologic conditions ...................................................................................... 3

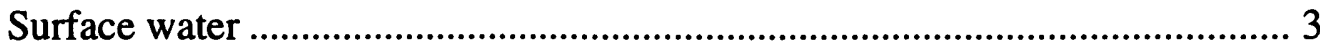

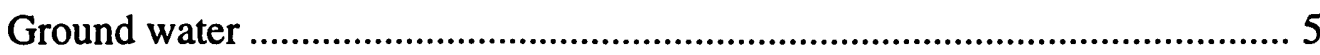

Guidelines for interpreting results of radiochemical analyses..................................... 5

Guidelines for interpreting results of inorganic and organic analyses......................... 7

Acknowledgments .................................................................................................. 7

Methods and quality assurance ....................................................................................... 7

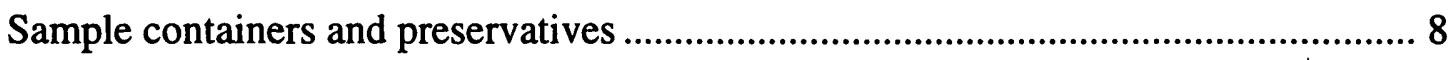

Sampling locations and sample collection ............................................................. 8

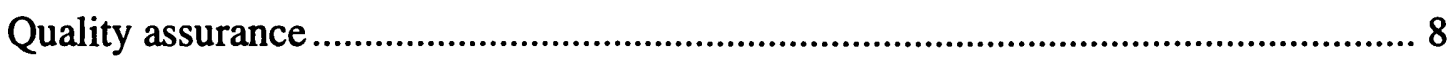

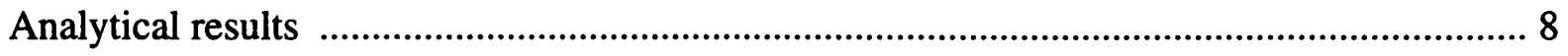

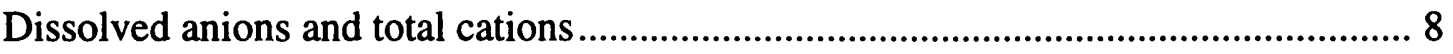

Total trace elements ................................................................................................. 9

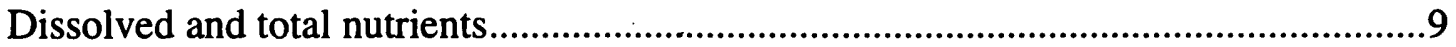

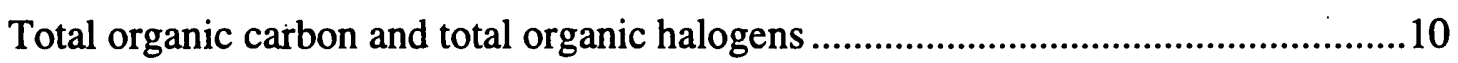

Gross alpha- and gross beta-particle radioactivity .......................................................10

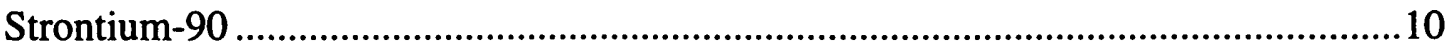

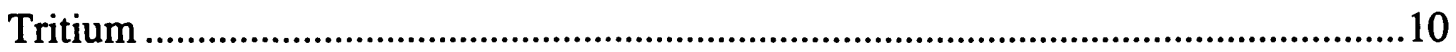

Selected gamma-emitting radioisotopes ................................................................... 10

Regulatory volatile and base/neutral organic compounds ........................................11

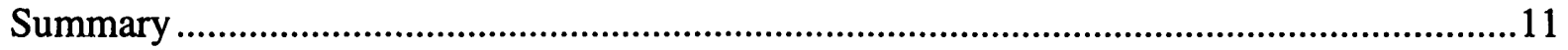

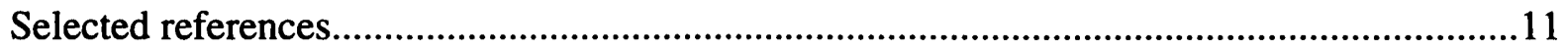

\section{FIGURES}

Figures 1-2. Maps showing:

1. Location of the Idaho National Engineering and Environmental Laboratory, Naval Reactors Facility, and other selected facilities.

2. Location of wells, Naval Reactors Facility and vicinity, Idaho National

Engineering and Environmental Laboratory .4

3. Water levels in two wells near the Naval Reactors Facility .....................................6 


\section{TABLES}

Table 1. Containers and preservatives used for water samples, Naval Reactors

Facility and vicinity....

2. Results of measurements of water for alkalinity, $\mathrm{pH}$, specific conductance, temperature, and turbidity, and calculated total dissolved solids, Naval Reactors Facility and vicinity.

3. Concentrations of dissolved anions and total cations in water, Naval Reactors Facility and vicinity

4. Concentrations of selected total trace elements in water, Naval Reactors Facility and vicinity...

5. Concentrations of dissolved and total nutrients, total organic carbon, and total organic halides in water, Naval Reactors Facility and vicinity...

6. Concentrations of gross alpha-particle radioactivity, gross beta-particle radioactivity, strontium-90, tritium, and selected isotopes from gamma spectroscopy in water, Naval Reactors Facility and vicinity

7. Regulatory volatile organic compounds for which water samples were analyzed .. 36

8. Base/neutral organic compounds for which water samples were analyzed 37

\section{CONVERSION FACTORS, VERTICAL DATUM, AND ABBREVIATED UNITS}

\section{Multiply}

foot $(\mathrm{ft})$

inch (in.)

mile (mi)

square mile $\left(\mathrm{mi}^{2}\right)$

acre-foot (acre-ft)

foot per mile $(\mathrm{ft} / \mathrm{mi})$

picocurie per liter (pCi/L)
By

0.3048

25.4

1.609

2.590

1,233

.1894

.037
To obtain

meter millimeter kilometer square kilometer cubic meter meter per kilometer becquerel per liter

For temperature, degrees Celsius $\left({ }^{\circ} \mathrm{C}\right)$ can be converted to degrees Fahrenheit $\left({ }^{\circ} \mathrm{F}\right)$ by using the equation: ${ }^{\circ} \mathrm{F}=(1.8)\left({ }^{\circ} \mathrm{C}\right)+32$.

Sea level: In this report, "sea level" refers to the National Geodetic Vertical Datum of 1929-a geodetic datum derived from a general adjustment of the first-order level nets of the United States and Canada, formerly called Sea Level Datum of 1929.

Abbreviated units used in report: $\mathrm{mg} / \mathrm{L}$ (milligram per liter); $\mu \mathrm{g} / \mathrm{L}$ (microgram per liter); $\mathrm{pCi} / \mathrm{L}$ (picocuries per liter). 


\title{
CHEMICAL AND RADIOCHEMICAL CONSTITUENTS IN WATER FROM WELLS IN THE VICINITY OF THE NAVAL REACTORS FACILITY, IDAHO NATIONAL ENGINEERING AND ENVIRONMENTAL LABORATORY, IDAHO, 1999
}

\author{
by Roy C. Bartholomay, LeRoy L. Knobel, Betty J. Tucker, and Brian V. Twining
}

\section{Abstract}

The U.S. Geological Survey, in response to a request from the U.S. Department of Energy's Pittsburgh Naval Reactors Office, Idaho Branch Office, sampled water from 13 wells during 1999 as part of a long-term project to monitor water quality of the Snake River Plain aquifer in the vicinity of the Naval Reactors Facility, Idaho National Engineering and Environmental Laboratory, Idaho. Water samples were analyzed for naturally occurring constituents and anthropogenic contaminants. A total of 52 samples were collected from the 13 monitoring wells. The routine samples contained detectable concentrations of total cations and dissolved anions, and nitrite plus nitrate as nitrogen. Most of the samples also contained detectable concentrations of gross alpha- and gross beta-particle radioactivity and tritium. Eight quality-assurance samples also were collected and analyzed; four were field-blank samples, and four were replicate samples. Most of the field blank samples contained less-than-detectable concentrations of target constituents.

\section{INTRODUCTION}

The Idaho National Engineering and Environmental Laboratory (INEEL), encompassing about $890 \mathrm{mi}^{2}$ of the eastern Snake River Plain in southeastem Idaho (fig. 1), is operated by the U.S. Department of Energy (DOE). INEEL facilities are used in the development of peacetime atomicenergy applications, nuclear safety research, defense programs, and advanced energy concepts. At the Naval Reactors Facility (NRF) (fig. 1), one facility at the INEEL, small amounts of some constituents have been released to the environment as described in two NRF Remedial Investigation/Feasibility Studies (Bettis Atomic Power Laboratory, 1994, 1997).
This study was conducted by the U.S. Geological Survey (USGS) in cooperation with the DOE's Pittsburgh Naval Reactors Office, Idaho Branch Office (IBO). IBO is responsible for the NRF at the INEEL. IBO requires information about the mobility of radionuclide- and chemical-waste constituents in the Snake River Plain aquifer. Wasteconstituent mobility is determined principally by (1) the rate and direction of ground-water flow; (2) the locations, quantities, and methods of waste disposal; (3) waste-constituent chemistry; and (4) the geochemical processes taking place in the aquifer (Orr and Cecil, 1991, p. 2).

\section{Purpose and Scope}

In 1989 , IBO requested that the USGS initiate a water-quality data-collection program in the vicinity of the NRF at the INEEL (fig. 1). The purpose of the data-collection program is to provide IBO with water-chemistry data to evaluate the effect of NRF activities on the water quality of the Snake River Plain aquifer.

Through 1995, the data-collection program consisted of three rounds of sample collection. Round one was a one-time sampling of each well for a comprehensive suite of chemical constituents that approximates those contained in the U.S. Environmental Protection Agency's (EPA) Ground-Water Monitoring List-Appendix IX (U.S. Environmental Protection Agency, 1989, p. 636-642). Round two consisted of bimonthly collection of samples five times from each well that were analyzed for the chemical constituents listed in Appendix IIIEPA Interim Primary Drinking Water Standards, the constituents listed as parameters establishing ground-water quality, and selected measurements used as indicators of ground-water contamination (U.S. Environmental Protection Agency, 1989, p. 660-661, 730). Additional constituents analyzed during round two included copper, nickel, zinc, and 


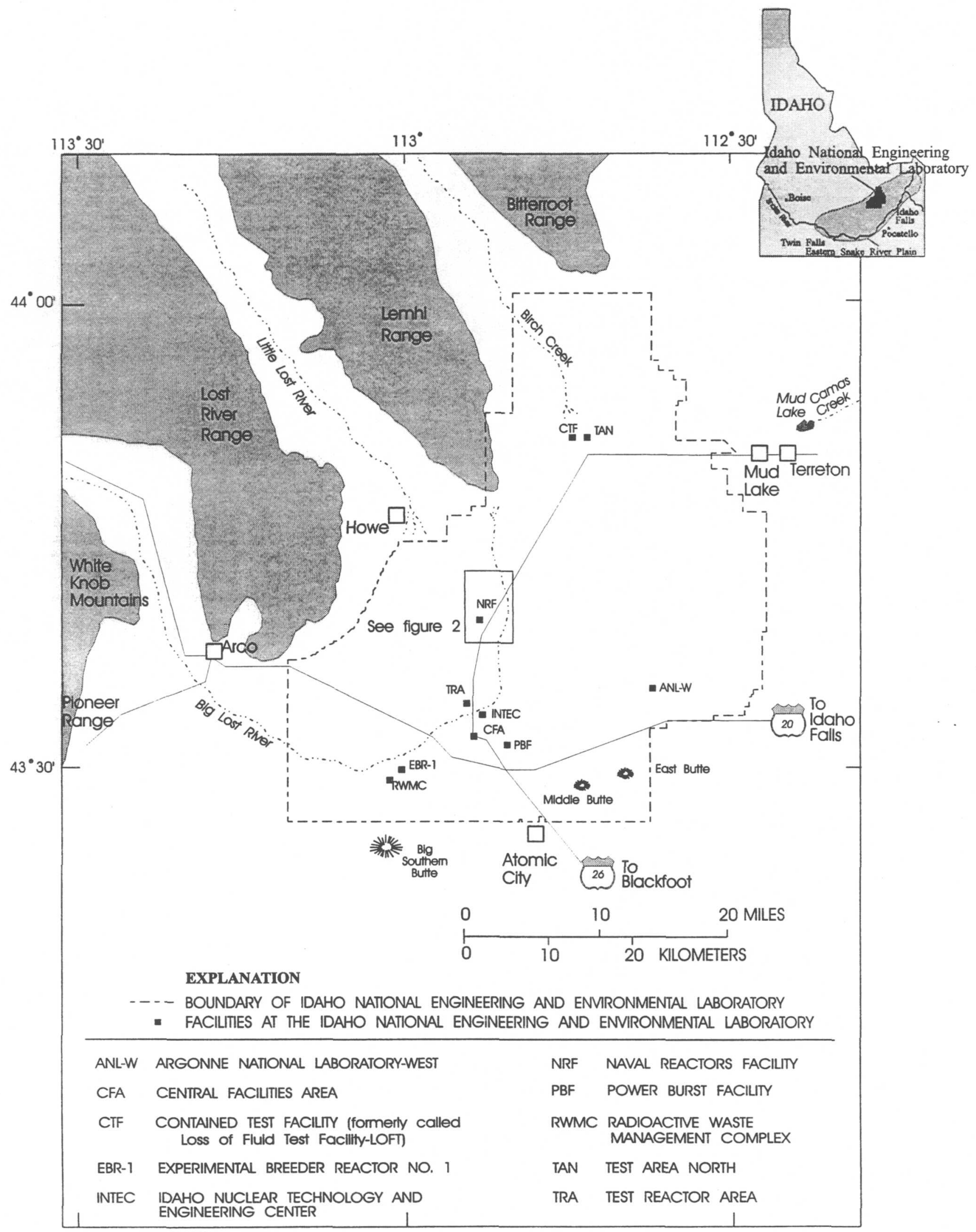

Figure 1. Location of the Idaho National Engineering and Environmental Laboratory, Naval Reactors Facility, and other selected facilities. 
extractable acid and base/neutral compounds. Round-three samples were collected quarterly through 1995. Constituents analyzed in 1994 included chloride, chromium, iron, lead, mercury, nickel, nitrate, silver, sodium, and sulfate. Other round-three measurements were gross alpha- and gross beta-particle radioactivity, $\mathrm{pH}$, specific conductance, and total organic carbon (TOC). The round-three sampling program was expanded in 1995 to include analyses for aluminum, antimony, arsenic, barium, beryllium, cadmium, copper, manganese, selenium, thallium, tritium, and zinc. As a result of expanded laboratory procedures, rounds one through three of the sample-collection program included analyses for constituents in addition to those listed above. Results of analyses of rounds one through three samples are presented by Knobel, Bartholomay, and others (1992), Bartholomay and others (1993), Tucker and others (1995), and Bartholomay, Knobel, and Tucker (1997).

An analysis by Westinghouse Electric Corporation of the water-chemistry data collected for the NRF monitoring program during 1989-95 indicated that several changes to the program would improve the overall usefulness of the data. As a result, several older wells were eliminated from the program and replaced by monitoring wells specifically constructed to meet NRF needs and strategically placed to better intercept potential chemical plumes in ground water. To differentiate between the data generated from the NRF sampling program in rounds one through three (1989-95) and subsequent data (1996), the samples collected in 1996 were designated round-four samples (Knobel and others, 1999). Wells sampled in rounds one through three that were eliminated from the program were four water-supply production wells with line shaft turbine pumps (NRF-1, $-2,-3$, and -4 ; fig. 2 ) and three monitoring wells (USGS 15, USGS 17, and Water Supply INEL-1; fig. 2) with dedicated submersible pumps. The six newly constructed monitoring wells that were added to the sampling program in 1996 were NRF-8, -9, -10, $11,-12$, and -13 (fig. 2). All of these wells and the older monitoring wells that remain in the monitoring network (NRF-6, NRF-7, USGS 12, 97, 98, 99, and 102; fig. 2) have dedicated submersible pumps.

At the end of 1996, NRF increased validation requirements for ground-water data on the basis of documents that supported the Record of Decision for the industrial waste ditch and NRF landfills. Because the USGS National Water Quality Laboratory (NWQL) could not supply this documentation cost effectively, NRF personnel sampled the wells during the first quarter of 1997. After further consideration of the program, it was determined that the sampling could be done under the USGS Department of Defense Environmental Conservation Program. Under this program, sample analyses are contracted to Quanterra Environmental Laboratory Services. Starting in June of 1997, water samples collected by the USGS were analyzed by the Quanterra laboratory. Results from the 1997-98 sampling were presented by Bartholomay and others (2000). This report presents results from the 1999 sampling. These samples are designated round-five samples. Location of wells sampled are shown in figure 2.

The constituent list for round-five samples was modified slightly from that from round-four samples because of availability of analyses at the laboratory. The constituents included in the round-five sampling program and analytical results are presented in tables 3 through 8 at the back of this report. Field measurements and calculations for round-five samples included alkalinity as $\mathrm{CaCO}_{3}$, $\mathrm{pH}$, specific conductance, temperature, total dissolved solids (TDS), and turbidity. Total dissolved solids were estimated by multiplying specific conductance by 0.543 as determined by Olmstead (1962, fig. 5). Round-five samples were collected quarterly at each well.

\section{Hydrologic Conditions}

The Snake River Plain aquifer is one of the most productive aquifers in the United States (U.S. Geological Survey, 1985, p. 193). The aquifer underlies the eastern Snake River Plain, a large, arcuate, structural basin in southeastern Idaho (fig. 1 ), and consists of a thick sequence of basalts and sedimentary interbeds.

\section{Surface Water}

The Big Lost River drains more than $1,400 \mathrm{mi}^{2}$ of mountainous area that includes parts of the Lost River Range and the Pioneer Range west of the INEEL (fig. 1). Flow in the Big Lost River infil- 


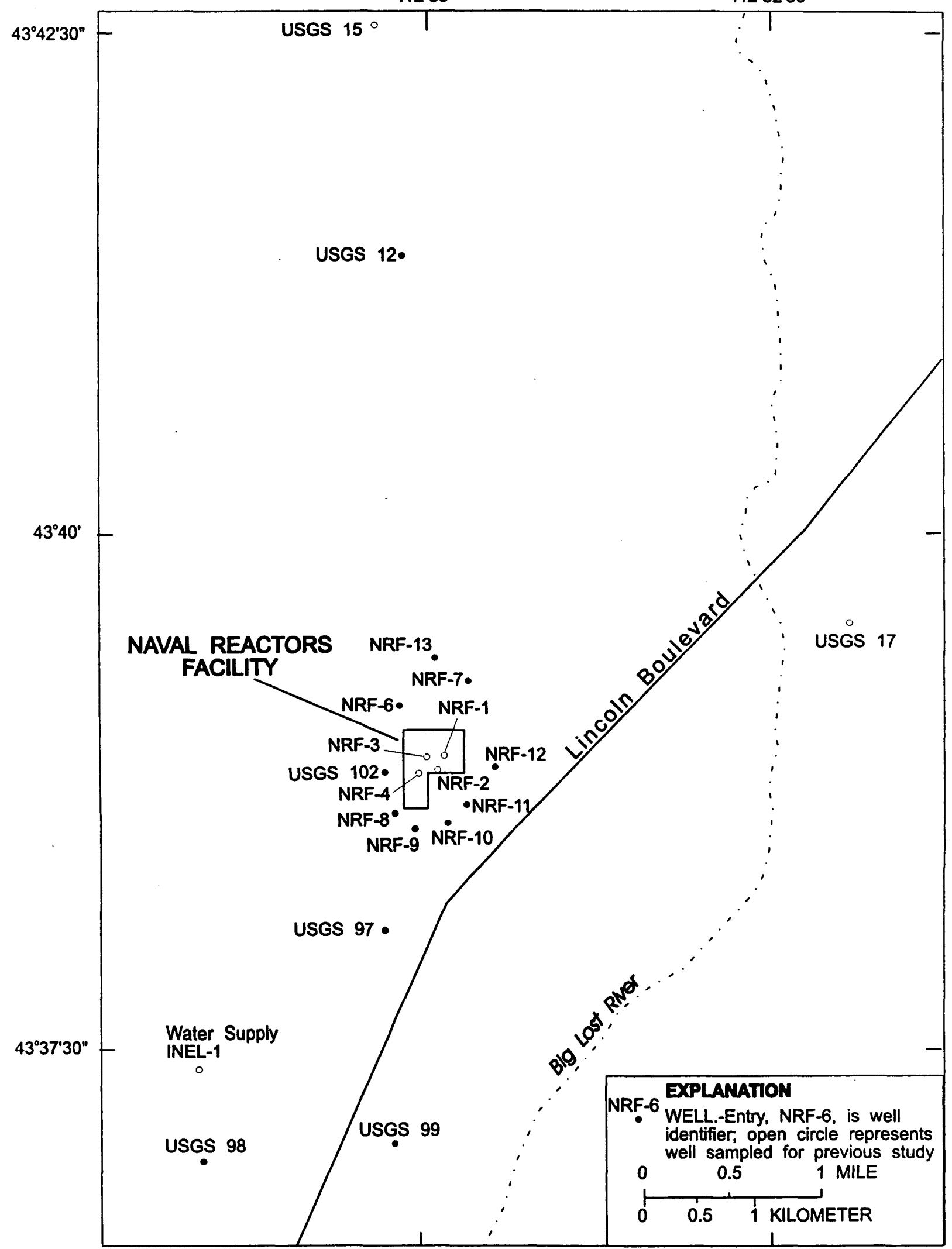

Figure 2. Location of wells, Naval Reactors Facility and vicinity, Idaho National Engineering and Environmental Laboratory. 
trates to the Snake River Plain aquifer along its channel and in sinks and playas near its terminus. Since 1965, excess runoff has been diverted to spreading areas in the southwestern part of the INEEL where much of the water rapidly infiltrates to the aquifer. Other surface drainages that recharge the Snake River Plain aquifer at the INEEL include the Little Lost River, Birch Creek, and Camas Creek (fig. 1) (Bartholomay, Tucker, and others, 1997, p. 18).

\section{Ground Water}

Recharge to the Snake River Plain aquifer is principally from infiltration of applied irrigation water, infiltration of streamflow, and ground-water inflow from adjoining mountain drainage basins. Some recharge may be from direct infiltration of precipitation, although the small amount of annual precipitation on the plain ( 8 in. at the INEEL), evapotranspiration, and the great depth to water (in places exceeding $900 \mathrm{ft}$ ) probably minimize this source of recharge (Orr and Cecil, 1991, p. 22-23).

Water in the Snake River Plain aquifer moves principally through fractures and interflow zones in the basalt. Most ground water moves through the upper $800 \mathrm{ft}$ of saturated rocks. Hydraulic conductivities of basalt in the upper $800 \mathrm{ft}$ of the aquifer, estimated from INEEL-wide transmissivity data, are from about 0.01 to $32,000 \mathrm{ft} /$ day (Anderson and others, 1999, p. 1). Estimated hydraulic conductivities in a 10,365-ft deep test hole near NRF are smaller; at depths exceeding $1,500 \mathrm{ft}$, hydraulic conductivities are from 0.002 to $0.03 \mathrm{ft} / \mathrm{day}$ (Mann, 1986, p. 21). The effective base of the Snake River Plain aquifer in the western part of the INEEL is from about 815 to $1,710 \mathrm{ft}$ below land surface (Anderson and others, 1996, table 3, p. 23).

Depth to water in wells completed in the Snake River Plain aquifer is from about $200 \mathrm{ft}$ below land surface in the northern part of the INEEL to more than $900 \mathrm{ft}$ in the southeastern part; in the vicinity of NRF, depth to water is about $375 \mathrm{ft}$ below land surface. In March-May 1995, the altitude of the water table was about 4,575 ft above sea level near Test Area North (fig. 1) and about 4,425 ft above sea level near the Radioactive Waste Management Complex (fig. 1); near the NRF, the water table was about $4,475 \mathrm{ft}$ above sea level. Water generally flows southward and southwestward beneath the INEEL at an average hydraulic gradient of about $4 \mathrm{ft} / \mathrm{mi}$; however, significant local variation in flow direction is common. Beneath the NRF, water generally flows southward. From March-May 1991 to March-May 1995, water-level changes in INEEL wells ranged from an 8.5-ft decline north of the $\mathrm{NRF}$ to a 2.5-ft decline in wells in the southern part of the INEEL; near the NRF, the water-level decline was about 6 to $8 \mathrm{ft}$. Water levels generally declined at the INEEL during 1992-95 because of drought (Bartholomay, Tucker, and others, 1997, p. 20-25), but since 1995, have risen (fig. 3).

Ground water moves southwestward from the INEEL and eventually discharges as springs along the Snake River downstream from Twin Falls, about $100 \mathrm{mi}$ southwest of the INEEL (fig. 1). Approximately 3.7 million acre-ft of ground water was discharged in 1995 (C.E. Berenbrock, USGS, written commun., 1996).

\section{Guidelines for Interpreting Results of Radiochemical Analyses}

Concentrations of radionuclides are reported with an estimated sample standard deviation, $s$, that is obtained by propagating sources of analytical uncertainty in measurements. The following guidelines for interpreting analytical results are based on an extension of a method proposed by Currie (1984).

In the analysis for a particular radionuclide, laboratory measurements are made on a target sample and a prepared blank. Instrument signals for the sample and the blank vary randomly. Therefore, it is essential to distinguish between two key aspects of the problem of detection: (1) the instrument signal for the sample must be larger than the signal observed for the blank before the decision can be made that the radionuclide was detected; and (2) an estimation must be made of the minimum radionuclide concentration that will yield a sufficiently large observed signal before the correct decision can be made for detection or nondetection of the radionuclide. The first aspect of the problem is a qualitative decision based on an observed signal and a definite criterion for detection. The second aspect of the problem is an estimation of the detection capabilities of a given measurement process. 


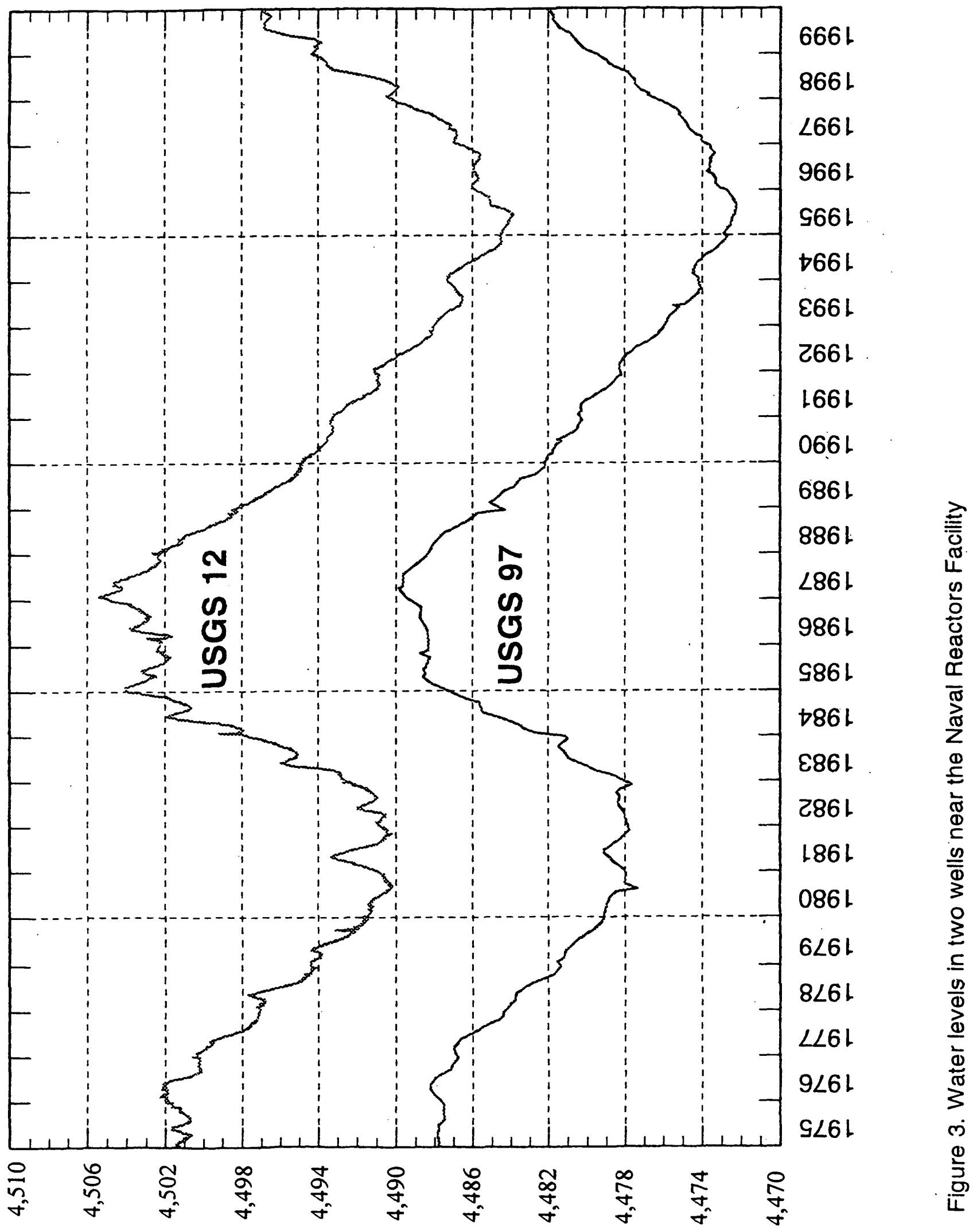

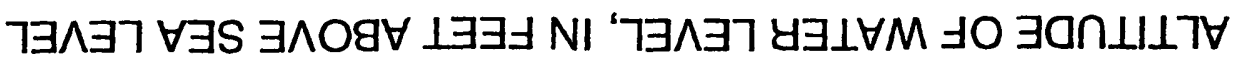


In the laboratory, instrument signals must exceed a critical level of $1.6 \mathrm{~s}$ before the qualitative decision can be made as to whether the radionuclide was detected. At 1.6s, there is a 95-percent probability that the correct conclusion-not detected-will be made. Given a large number of samples, as many as 5 percent of the samples with measured concentrations larger than or equal to $1.6 \mathrm{~s}$, which were concluded as being detected, might not contain the radionuclide. These measurements are referred to as false positives and are errors of the first kind in hypothesis testing.

Once the critical level of $1.6 \mathrm{~s}$ has been defined, the minimum detectable concentration can be determined. Radionuclide concentrations that equal 3 s represent a measurement at the minimum detectable concentration. For true concentrations of $3 \mathrm{~s}$ or larger, there is a 95-percent or larger probability that the radionuclide was detected in a sample. In a large number of samples, the conclusion-not detected-will be made in 5 percent of the samples that contain true concentrations at the minimum detectable concentration of $3 \mathrm{~s}$. These measurements are referred to as false negatives and are errors of the second kind in hypothesis testing.

True radionuclide concentrations between 1.6s and $3 \mathrm{~s}$ have larger errors of the second kind. That is, there is a larger-than-5-percent probability of false negative results for samples with true concentrations between $1.6 \mathrm{~s}$ and $3 \mathrm{~s}$. Although the radionuclide might have been detected, such detection may not be considered reliable; at $1.6 \mathrm{~s}$, the probability of a false negative is about 50 percent.

The critical level and minimum detectable concentration are based on counting statistics alone and do not include systematic or random errors inherent in laboratory procedures. The values $1.6 \mathrm{~s}$ and $3 \mathrm{~s}$ vary slightly with background or blank counts, with the number of gross counts for individual analyses, and for different radionuclides. In this report, radionuclide concentrations less than $3 \mathrm{~s}$ are considered to be below a "reporting level." The critical level, minimum detectable concentration, and reporting level aid the reader in the interpretation of analytical results and do not represent absolute concentrations of radioactivity which may or may not have been detected.
Many analytical results of environmental radioactivity measurements are at or near zero. If the true concentration for a given radionuclide is zero, a given set of analytical results for that radionuclide should be distributed about zero, with an equal number of negative and positive measurements. Negative analytical results occur if the radioactivity of a water sample is less than the background radioactivity or the radioactivity of the prepared blank sample in the laboratory (American Society for Testing and Materials, 1992, p. 126; Knobel, Orr, and Cecil, 1992, p. 51).

\section{Guidelines for Interpreting Results of Inorganic and Organic Analyses}

The term "reporting level" used for radiochemical analyses should not be confused with the term "reporting limit" used for inorganic and organic " analyses. In this report, the term "reporting limit" is the lowest level at which measurements become quantitatively meaningful (Quanterra Environmental Services, 1998). Because of unpredictable matrix effects on detection limits, the laboratory reporting limits are set somewhat higher than the analytical method detection limits. Because of this, some estimated results are given.

\section{Acknowledgments}

The authors are grateful to Robert Hermandson of the USGS for checking data tables with original data and Kelly D. Willie of Bechtel-Bettis Corporation and Jeff Langman of the USGS for technically reviewing the manuscript.

\section{METHODS AND QUALITY ASSURANCE}

The methods used for collecting water samples generally followed the guidelines established by the USGS (Stevens and others, 1975; Wood, 1981; Claassen, 1982; W.L. Bradford, USGS, written commun., 1985; Hardy and others, 1989; Wilde and others, 1998). Descriptions of methods used for analysis are found in Quanterra Environmental Services (1998) and Thatcher and others (1977). The methods used in the field and the qualityassurance practices are described in the following sections. 


\section{Sample Containers and Preservatives}

Sample containers and preservatives differed depending on the constituent(s) for which analyses were requested. Samples were placed in prepreserved containers in accordance with bottle-manufacturer requirements. Containers and preservatives were supplied by the Quanterra Environmental Services Laboratory. The containers and preservatives used for this study are listed in table 1 (all tables located at the end of report).

\section{Sampling Locations and Sample Collection}

Samples were.collected from 13 monitoring wells (NRF-6, -7, -8, -9, -10, -11, -12, -13, USGS $12,97,98,99$, and 102) equipped with dedicated submersible pumps. NRF-6, -7, -13, and USGS 12 are upgradient of the NRF; USGS 102 is west of NRF; NRF-11 and -12 are east of NRF; and the remaining monitoring wells are downgradient of NRF (fig. 2).

Samples were collected from a portable sampling apparatus attached to the dedicated submersible pumps. The apparatus was decontaminated before sampling at each site by rinsing with deionized water. Samples were collected after three well-bore volumes of water were purged from each well and field measurements indicated probable hydraulic and chemical stability. After collection, sample containers were sealed with laboratory film, labeled, and stored under secured conditions. Water samples were placed in ice chests, chilled when appropriate, sealed, and shipped the same day to the laboratory.

Conditions at the sampling site during sample collection were recorded in a field logbook, and a chain-of-custody record was used to track samples from the time of collection until delivery to the laboratory. These records are available for inspection at the USGS INEEL Project Office. The results of field measurements and calculations for alkalinity, $\mathrm{pH}$, specific conductance, water temperature, TDS, and turbidity are listed in table 2.

\section{Quality Assurance}

Internal quality control and the overall qualityassurance practices used by the Quanterra Labora- tory are described in a report by Quanterra Environmental Services (1998). The water samples were collected by personnel assigned to the INEEL Project Office in accordance with a quality-assurance plan for quality-of-water activities. The plan was finalized in June 1989, revised in March 1992 and again in 1996 (Mann, 1996), and is available from the USGS INEEL Project Office. Comparative studies to determine agreement between analytical results for water-sample pairs by laboratories involved in the INEEL Project Office's quality-assurance program are summarized by Wegner (1989), Williams (1996), and Williams (1997). Additional quality assurance used for this sampling program included four field-blank samples prepared with inorganic-free and organicfree water and four replicate samples. Bottles for the field-blank samples were filled in the field camper with the respective inorganic and organicfree water. Inorganic-free water was used for the radiochemical blanks. Respective bottles then were opened at the well while sample collection occurred. After collection of the primary sample, a replicate sample was immediately collected. Many organizations use the term "sequential replicate" rather than "replicate" sample.

\section{ANALYTICAL RESULTS}

During the period beginning in February 1999 and ending in November 1999, four sets of quarterly water samples were collected for round five of the NRF sampling program (table 2). All wells were sampled four times. Quality-assurance samples included four field-blank samples; NRF-6 (QAS-73), NRF-10 (QAS-68), NRF-11 (QAS-72), NRF-13 (QAS-70), and four replicate samples: NRF-9 (QAS-74), NRF-12 (QAS-67), USGS 97 (QAS-69), and USGS 98 (QAS-71).

\section{Dissolved Anions and Total Cations}

Water samples were analyzed for concentrations of dissolved chloride and sulfate and concentrations of total calcium, magnesium, potassium, and sodium (table 3 ).

Concentrations of calcium in samples from the 13 wells ranged from 27.1 to $117 \mathrm{mg} / \mathrm{L}$. Concentrations of chloride ranged from 5.1 to $228 \mathrm{mg} / \mathrm{L}$. Concentrations of magnesium ranged from 9.5 to 
$30.4 \mathrm{mg} / \mathrm{L}$. Estimated concentrations of potassium ranged from 1.6 to $4.7 \mathrm{mg} / \mathrm{L}$. Concentrations of sodium ranged from 8.2 to $95.6 \mathrm{mg} / \mathrm{L}$. Concentrations of sulfate ranged from 13.2 to $138 \mathrm{mg} / \mathrm{L}$.

Concentrations in the four field-blank samples were not detected except in QAS-73, which contained an estimated concentrations of $0.015 \mathrm{mg} / \mathrm{L}$ for calcium and $0.60 \mathrm{mg} / \mathrm{L}$ for sodium; and QAS-72 and -70, which contained estimated concentrations of 0.07 and $0.064 \mathrm{mg} / \mathrm{L}$, respectively, for calcium and 0.02 and $0.014 \mathrm{mg} / \mathrm{L}$, respectively, for magnesium.

\section{Total Trace Elements}

Water samples collected in 1999 were analyzed for concentrations of total aluminum, antimony, arsenic, barium, beryllium, cadmium, chromium, copper, iron, lead, manganese, mercury, nickel, selenium, silver, thallium, and zinc (table 4).

Aluminum.-Aluminum was detected in most samples from most wells; detectable concentrations ranged from an estimated $15 \mu \mathrm{g} / \mathrm{L}$ in USGS 12 to $3,800 \mu \mathrm{g} / \mathrm{L}$ in a sample from NRF-13.

Antimony.-Antimony was not detected in any but one sample; one sample from USGS 97 contained an estimated concentration of $3.2 \mu \mathrm{g} / \mathrm{L}$.

Arsenic.-Arsenic was not detected in any but one sample; one sample from NRF-6 contained an estimated concentration of $4.2 \mu \mathrm{g} / \mathrm{L}$.

Barium.-Concentrations of barium ranged from $55.2 \mu \mathrm{g} / \mathrm{L}$ in USGS 98 to $180 \mu \mathrm{g} / \mathrm{L}$ in NRF-12.

Beryllium.-Beryllium was not detected in most samples.

Cadmium.-Cadmium was not detected in any samples.

Chromium.-Concentrations of chromium ranged from an estimated $4.6 \mu \mathrm{g} / \mathrm{L}$ in USGS 99 to $92 \mu \mathrm{g} / \mathrm{L}$ in NRF-13.

Copper.-Copper was not detected in most samples.

Iron.-Iron was detected in most samples; detectable concentrations ranged from an estimated $9.0 \mu \mathrm{g} / \mathrm{L}$ in USGS 97 to $3,500 \mu \mathrm{g} / \mathrm{L}$ in a sample from NRF-13.
Lead.-Lead was not detected in many samples; detectable concentrations were as large as $9.2 \mu \mathrm{g} / \mathrm{L}$ in a sample from USGS 97 .

Manganese.-Manganese was not detected in many samples; detectable concentrations were as large as $67 \mu \mathrm{g} / \mathrm{L}$ in a sample from NRF-13.

Mercury.-Mercury was not detected in most samples.

Nickel.- -Nickel was not detected in most samples; detectable concentrations were as large as $41.8 \mu \mathrm{g} / \mathrm{L}$ in a sample from NRF-13.

Selenium.-Selenium was detected in only two samples.

Silver.-Silver was not detected in any samples.

Thallium.-Thallium was detected in only two samples.

Zinc.-Zinc was not detected in many samples; detectable concentrations were as large as $180 \mu \mathrm{g} / \mathrm{L}$ in a sample from USGS 98.

Field-blank samples contained either no detectable concentrations of trace elements or had estimated concentrations smaller than the respective reporting limits.

\section{Dissolved and Total Nutrients}

Water samples were analyzed for concentrations of dissolved nitrite as nitrogen and for total concentrations of kjeldahl nitrogen, nitrite plus nitrate as nitrogen and phosphorus as phosphorus (table 5).

Kjeldahl nitrogen.-Kjeldahl nitrogen was not detected in most samples; detectable concentrations were as large as $0.89 \mathrm{mg} / \mathrm{L}$ in a sample from USGS 102.

Nitrite as nitrogen.-Nitrite as nitrogen was not detected in most samples; detectable concentrations were as large as $0.33 \mathrm{mg} / \mathrm{L}$ in a sample from NRF-7.

Nitrite plus nitrate as nitrogen.-Concentrations ranged from $0.47 \mathrm{mg} / \mathrm{L}$ in NRF-6 and -7 to $2.4 \mathrm{mg} / \mathrm{L}$ in USGS 97 and USGS 102.

Phosphorus as phosphorus.-Phosphorus as phosphorus was detected in most samples; detect- 
able concentrations were as large as $0.13 \mathrm{mg} / \mathrm{L}$ in a sample from NRF-13.

Field-blank samples contained either no detectable concentrations of nutrients or had estimated concentrations smaller than the reporting limits.

\section{Total Organic Carbon and Total Organic Halogens}

Water samples were analyzed for concentrations of TOC and total organic halogens (TOX) (table 5). TOC and TOX were not detected in most samples. TOC and TOX were not detected in any blank samples.

\section{Gross Alpha- and Gross Beta-Particle Radioactivity}

Water samples were analyzed for concentrations of dissolved gross alpha- and gross betaparticle radioactivity by the Quanterra Laboratory in Richland, Wash. through a contract with the NWQL using a residue procedure. Concentrations of radioactive constituents larger than or equal to 3 times the $1 \mathrm{~s}$ uncertainty are considered to be above the reporting level in this report. All analytical measurements are listed in table 6 . For a more detailed discussion of reporting levels for radioactive constituents and measurements, see the section of this report titled "Guidelines for Interpreting Results of Radiochemical Analyses."

Gross alpha-particle radioactivity.-Gross alpha-particle radioactivity is a measure of the total radioactivity given off as alpha particles during the radioactive decay process. For convenience, laboratories report the radioactivity as if it all were given off by one radionuclide. In this report, concentrations are reported as thorium-230 in picocuries per liter. Concentrations of dissolved gross alpha-particle radioactivity are listed in table 6 .

Concentrations of gross alpha-particle radioactivity as thorium-230 ranged from $-0.34 \pm 0.12$ $\mathrm{pCi} / \mathrm{L}$ in NRF-12 to $8.0 \pm 2.4 \mathrm{pCi} / \mathrm{L}$ in NRF-6. Concentrations in all the field blank samples were less than the reporting level.

Gross beta-particle radioactivity--Gross betaparticle radioactivity is a measure of the total radioactivity given off as beta particles during the radioactive decay process. For convenience, laboratories report the radioactivity as if it all were given off by one radionuclide, cesium-137, in picocuries per liter. Concentrations of dissolved gross beta-particle radioactivity are listed in table 6 .

Concentrations of gross beta-particle radioactivity as cesium- 137 ranged from $0.34 \pm 0.75 \mathrm{pCi} / \mathrm{L}$ in NRF-6 to $7.6 \pm 1.0 \mathrm{pCi} / \mathrm{L}$ in NRF-6. Concentrations in all the field blank samples were less than the reporting level.

\section{Strontium-90}

Water samples were analyzed for strontium- 90 by chemical separation and beta counting (table 6). The concentrations of strontium-90 in all but one regular sample and in all field-blank samples were less than the reporting level. A sample from $\mathrm{NRF}-12$ contained $0.49 \pm 0.16 \mathrm{pCi} / \mathrm{L}$.

\section{Tritium}

Water samples were analyzed for tritium by the University of Georgia Center for Isotopic Studies Laboratory through a contract with the NWQL by enrichment and liquid scintillation (table 6). Concentrations of tritium ranged from $<3.57 \mathrm{pCi} / \mathrm{L}$ in NRF-7 to $200 \pm 28 \mathrm{pCi} / \mathrm{L}$ in NRF-11. The concentrations of tritium in field blank samples ranged from $14 \pm 1.5 \mathrm{pCi} / \mathrm{L}$ in QAS-73 (blank for NRF-6) to $51 \pm 4.8 \mathrm{pCi} / \mathrm{L}$ in QAS-70 (blank for NRF-13).

\section{Selected Gamma-Emitting Radioisotopes}

Gamma spectrometry involves using a series of detectors to simultaneously determine the concentrations of a variety of radionuclides by the detection of their characteristic gamma emissions. Radionuclides identified in selected samples include cobalt -60 , cesium-137, potassium- 40 , radium-226, radium-228, thorium-228, uranium235 , uranium-238, and thallium-208. Concentrations of all the radionuclides identified using gamma spectrometry are given in table 6 .

Concentrations reported as cesium-137 in all the regular field blank samples were less than the reporting level. 


\section{Regulatory Volatile and Base/Neutral Organic Compounds}

Water samples collected in July 1999 were analyzed for 59 regulatory volatile organic compounds (table 7) and 17 base/neutral organic compounds (table 8). Concentrations of chloroform and tetrachloroethylene in one sample (NRF-6) were 0.2 and $0.3 \mu \mathrm{g} / \mathrm{L}$, respectively. Concentrations of regulatory volatile organic compounds in all other samples were less than the reporting limits. Concentrations of $\mathrm{Di}(2$-ethylhexyl) phthalate in two samples (NRF-9 and USGS 97) were 0.6 and $1.2 \mu \mathrm{g} / \mathrm{L}$, respectively. Concentrations of base/neutral organic compounds in all other samples were less than the reporting limits.

\section{SUMMARY}

The USGS, in response to a request from the U.S. Department of Energy's Pittsburgh Naval Reactors Office, Idaho Branch Office, sampled 13 wells during 1999 as part of a long-term project to monitor water quality of the Snake River Plain aquifer in the vicinity of the NRF, INEEL, Idaho. Water samples were collected and analyzed for naturally occurring constituents and anthropogenic contaminants. A total of 52 samples were collected from 13 monitoring wells with dedicated submersible pumps. Eight quality-assurance samples also were collected and analyzed; four were field-blank samples and four were replicate samples.

The ranges of concentrations of dissolved anions and total cations follow: calcium, 27.1 to $117 \mathrm{mg} / \mathrm{L}$; chloride, 5.1 to $228 \mathrm{mg} / \mathrm{L}$; magnesium, 9.5 to $30.4 \mathrm{mg} / \mathrm{L}$; potassium, 1.6 to $4.7 \mathrm{mg} / \mathrm{L}$; sodium, 8.2 to $95.6 \mathrm{mg} / \mathrm{L}$; and sulfate, 13.2 to 138 $\mathrm{mg} / \mathrm{L}$.

Samples were analyzed for 17 trace elements. Antimony, arsenic, beryllium, cadmium, copper, manganese, mercury, nickel, selenium, silver, thallium, and zinc were not detected in most samples. concentrations of manganese, nickel, and zinc were as large as $67,41.8$, and $180 \mu \mathrm{g} / \mathrm{L}$, respectively. Aluminum, lead, and iron were detected in most samples. The largest concentration of iron was $3,500 \mu \mathrm{g} / \mathrm{L}$. The ranges of concentrations for barium and chromium were 55.2 to $180 \mu \mathrm{g} / \mathrm{L}$ and 4.6 to $72 \mu \mathrm{g} / \mathrm{L}$, respectively. Concentrations of the predominant nitrogen-bearing compound, nitrite plus nitrate as nitrogen, ranged from 0.47 to $2.4 \mu \mathrm{g} / \mathrm{L}$.

TOC and TOX were not detected in most samples.

Concentrations of dissolved gross alpha- and gross beta-particle radioactivity and tritium exceeded the reporting level in most samples. Concentrations of strontium- 90 and gross gamma as cesium-137 were less than the reporting level in most samples.

Concentrations of two regulatory volatile organic compounds were detected in one sample. Concentrations of the base/neutral organic compound $\mathrm{Di}$ (2-ethylhexyl) phthalate were detected in two samples. All of the field blank samples contained concentrations of the constituents that were less than the reporting limits.

\section{SELECTED REFERENCES}

Ackerman, D.J., 1991, Transmissivity of the Snake River Plain aquifer at the Idaho National Engineering Laboratory, Idaho: U.S. Geological Survey Water-Resources Investigations Report 91-4058 (DOE/ID22097), 35 p.

American Society for Testing and Materials, 1992, ASTM standards on precision and bias for various applications: Philadelphia, $\mathrm{Pa}$., American Society for Testing and Materials Publication code number (PCN) 03-51109234, $478 \mathrm{p}$.

American Society for Testing and Materials, 1998, Standard method for high-resolution gammaray spectrometry of water (D3649-91): Philadelphia, Pa., American Society of Testing and Materials 1998 Annual Book of ASTM Standards, v. 11.02, 1,048 p.

Anderson, S.R., Ackerman, D.J., Liszewski, M.J., and Freiburger, R.M., 1996, Stratigraphic data for wells at and near the Idaho National Engineering Laboratory, Idaho: U.S. Geological Survey Open-File Report 96-248 (DOE/ID-22127), 27 p., 1 diskette. 
Anderson, S.R., Kuntz, M.A., and Davis, L.C., 1999, Geologic controls of hydraulic conductivity in the Snake River Plain aquifer at and near the Idaho National Engineering and Environmental Laboratory, Idaho: U.S. Geological Survey Water-Resources Investigations Report 99-4033 (DOE/ID22155), $38 \mathrm{p}$.

Bartholomay, R.C., Knobel, L.L., and Tucker, B.J., 1993, Chemical constituents in water from wells in the vicinity of the Naval Reactors Facility, Idaho National Engineering Laboratory, Idaho, 1990-91: U.S. Geological Survey Open-File Report 93-94 (DOE/ID22106), 70 p.

1997, Chemical and radiochemical constituents in water from wells in the vicinity of the Naval Reactors Facility, Idaho National Engineering Laboratory, Idaho, 1994-95: U.S. Geological Survey Open-File Report 97 806 (DOE/ID-22143), 70 p.

Bartholomay, R.C., Knobel, L.L., Tucker, B.J., and Twining, B.V., 2000, Chemical and radiochemical constituents in water from wells in the vicinity of the Naval Reactors Facility, Idaho National Engineering and Environmental Laboratory, Idaho, 1997-98: U.S. Geological Survey Open-File Report 00-236 (DOE/ID-22165), $52 \mathrm{p}$.

Bartholomay, R.C., Tucker, B.J., Ackerman, D.J., and Liszewski, M.J., 1997, Hydrologic conditions and distribution of selected radiochemical and chemical constituents in water, Snake River Plain aquifer, Idaho National Engineering Laboratory, Idaho, 1992 through 1995: U.S. Geological Survey WaterResources Investigations Report 97-4086 (DOE/ID-22137), 57 p.

Bettis Atomic Power Laboratory Naval Reactors

Facility, 1994, Remedial investigation/ feasibility study for the external industrial waste ditch, operable unit 8-07: Westinghouse Electric Corporation NRFRCEC-1046, 26 p.
_1997, NRF comprehensive remedial investigation/feasibility study, waste area group 8: Westinghouse Electric Corp., [unpaginated].

Claassen, H.C., 1982, Guidelines and techniques for obtaining water samples that accurately represent the water chemistry of an aquifer: U.S. Geological Survey Open-File Report 82-1024, 49 p.

Currie, L.A., 1984, Lower limit of detection-Definition and elaboration of a proposed position for radiological effluent and environmental measurements: U.S. Nuclear Regulatory Commission NUREG/CR-4077, $139 \mathrm{p}$.

Hardy, M.A., Leahy, P.P., and Alley, W.M., 1989, Well installation and documentation, and ground-water sampling protocols for the pilot National Water-Quality Assessment Program: U.S. Geological Survey Open-File Report 89-396, 36 p.

Iman, R.L., and Conover, W.J., 1983, A modern approach to statistics: New York, John Wiley \& Sons, Inc., 497 p.

Knobel, L.L., Bartholomay, R.C., Tucker, B.J., and Williams, L.M., 1999, Chemical and radiochemical constituents in water from wells in the vicinity of the Naval Reactors Facility, Idaho National Engineering and Environmental Laboratory, Idaho, 1996: U.S. Geological Survey Open-File Report 99-272 (DOE/ID-22160), $58 \mathrm{p}$.

Knobel, L.L., Bartholomay, R.C., Wegner, S.J., and Edwards, D.D., 1992, Chemical constituents in water from wells in the vicinity of the Naval Reactors Facility, Idaho National Engineering Laboratory, Idaho, 1989-90:

U.S. Geological Survey Open-File Report 92156 (DOE/ID-22103), 38 p.

Knobel, L.L., Orr, B.R., and Cecil, L.D., 1992, Summary of background concentrations of selected radiochemical and chemical constituents in groundwater from the Snake 
River Plain aquifer, Idaho-estimated from an analysis of previously published data: Journal of the Idaho Academy of Science, v. 28, no. 1, p. 48-61.

Mann, L.J., 1986, Hydraulic properties of rock units and chemical quality of water for INEL1-a 10,365-foot deep test hole drilled at the Idaho National Engineering Laboratory, Idaho: U.S. Geological Survey WaterResources Investigations Report 86-4020 (DOE/ID-22070), 23 p.

1989, Tritium concentrations in flow from selected springs that discharge to the Snake River, Twin Falls-Hagerman area, Idaho: U.S. Geological Survey Water-Resources Investigations Report 89-4156 (DOE/ID22084), 20 p.

1996, Quality-assurance plan and field methods for quality-of-water activities, U.S. Geological Survey, Idaho National Engineering Laboratory, Idaho: U.S. Geological Survey Open-File Report 96-615 (DOE/ID-22132), 37 p.

Olmstead, F.H., 1962, Chemical and physical character of ground water in the National Reactor Testing Station, Idaho: U.S. Atomic Energy Commission Publication IDO-22043, $81 \mathrm{p}$.

Orr, B.R., and Cecil, L.D., 1991, Hydrologic conditions and distribution of selected chemical constituents in water, Snake River Plain aquifer, Idaho National Engineering Laboratory, Idaho, 1986 to 1988: U.S. Geological Survey Water-Resources Investigations Report 91-4047 (DOE/ID22096), 56 p.

Quanterra Environmental Services, 1998, Quality Assurance Management Plan for environmental services, revision 3: Quanterra Environmental Services, [variously paged].

Stevens, H.H., Jr., Ficke, J.F., and Smoot, G.F., 1975, Water temperature-influential factors, field measurement, and data presentation: U.S. Geological Survey Techniques of WaterResources Investigations, book 5, chap. D1, $65 \mathrm{p}$.
Thatcher, L.L., Janzer, V.J., and Edwards, K.W., 1977 , Methods for determination of radioactive substances in water and fluvial sediments: U.S. Geological Survey Techniques of Water-Resources Investigations, book 5, chap. A5, 95 p.

Tucker, B.J., Knobel, L.L., and Bartholomay, R.C., 1995, Chemical constituents in water from wells in the vicinity of the Naval Reactors Facility, Idaho National Engineering Laboratory, Idaho, 1991-93: U.S. Geological Survey Open-File Report 95-725 (DOE/ID22125), 94 p.

U.S. Environmental Protection Agency, 1989, Protection of Environment, Code of Federal Regulations 40: Office of the Federal Register, National Archives and Records Administration, pts. 190 to 299, 1,027 p.

U.S. Geological Survey, 1985, National water summary, 1984_-Hydrologic events, selected water-quality trends, and ground-water resources: U.S. Geological Survey WaterSupply Paper 2275, 467 p.

Wegner, S.J., 1989, Selected water quality assurance data for water samples collected by the U.S. Geological Survey, Idaho National Engineering Laboratory, Idaho, 1980 to 1988 : U.S. Geological Survey Water-Resources Investigations Report 89-4168 (DOE/ID22085), $91 \mathrm{p}$.

Wilde, F.D., Radtke, D.B., Gibs, J., and Iwatsubo, R.T., 1998, National field manual for the collection of water-quality data: U.S. Geological Survey Techniques of WaterResources Investigations, book 9, [variously paged].

Williams, L.M., 1996, Evaluation of quality assurance/quality control data collected by the U.S. Geological Survey for water-quality activities at the Idaho National Engineering Laboratory, Idaho, 1989 through 1993: U.S. Geological Survey Water-Resources Investigations Report 96-4148 (DOE/ID22129), $116 \mathrm{p}$. 
1997, Evaluation of quality assurance/quality control data collected by the U.S. Geological Survey for water-quality activities at the Idaho National Engineering Laboratory, Idaho, 1994 through 1995: U.S. Geological Survey WaterResources Investigations Report 97-4058 (DOE/ID-22136), 87 p.
Wood, W.W., 1981, Guidelines for collection and field analysis of ground-water samples for selected unstable constituents: U.S. Geological Survey Techniques of WaterResources Investigations, book 1, chap. D2, $24 \mathrm{p}$. 
Table 1. Containers and preservatives used for water samples, Naval Reactors Facility and vicinity

[Analyses were performed by Quanterra Laboratory. Abbreviations: $\mathrm{L}$, liter; $\mathrm{mL}$, milliliter. Symbols: $\mathrm{HNO}_{3}$, nitric acid; $\mathrm{H}_{2} \mathrm{SO}_{4}$, sulfuric acid; $\mathrm{HCL}$, hydrochloric acid; ${ }^{\circ} \mathrm{C}$, degrees Celsius. Samples were shipped by overnight-delivery mail]

\begin{tabular}{|c|c|c|c|c|c|}
\hline \multirow[b]{2}{*}{ Type of constituent } & \multicolumn{2}{|c|}{ Container } & \multicolumn{2}{|c|}{ Preservative } & \multirow{2}{*}{$\begin{array}{l}\text { Other } \\
\text { treatment }\end{array}$} \\
\hline & Type & Size & Type & Volume & \\
\hline Anions & Polyethylene & $1 \mathrm{~L}$ & None & None & Filter \\
\hline Cations, total recoverable & Polyethylene & $500 \mathrm{~mL}$ & $\mathrm{HNO}_{3}$ & $10 \mathrm{~mL}$ & None \\
\hline Trace elements, total recoverable & Polyethylene & $500 \mathrm{~mL}$ & $\mathrm{HNO}_{3}$ & $10 \mathrm{~mL}$ & None \\
\hline Nitrite & Polyethylene & $1 \mathrm{~L}$ & None & None & Filter \\
\hline Nutrients, total recoverable & Glass, baked & $500 \mathrm{~L}$ & $\mathrm{H}_{2} \mathrm{SO}_{4}$ & $2 \mathrm{~mL}$ & Chill $4^{\circ} \mathrm{C}$ \\
\hline Specific conductance & Polyethylene & $1 \mathrm{~L}$ & None & None & Filter \\
\hline Total organic carbon & Glass, baked & $500 \mathrm{~L}$ & $\mathrm{H}_{2} \mathrm{SO}_{4}$ & $2 \mathrm{~mL}$ & Chill $4^{\circ} \mathrm{C}$ \\
\hline Total organic halogens & Glass, baked & $250 \mathrm{~mL}$ & $\mathrm{H}_{2} \mathrm{SO}_{4}$ & $1 \mathrm{~mL}$ & Chill $4^{\circ} \mathrm{C}$ \\
\hline Purgeable organic compounds & Glass, baked & $40 \mathrm{~mL}$ & HCL & 4 drops & Chill \\
\hline $\begin{array}{l}\text { Semi-volatile organic } \\
\text { compounds }\end{array}$ & Glass, baked & IL & None & None & Chill \\
\hline Gamma & $\begin{array}{l}\text { Polyethylene, } \\
\text { acid-rinsed }\end{array}$ & IL & $\mathrm{HNO}_{3}$ & $20 \mathrm{~mL}$ & Filter \\
\hline $\begin{array}{l}\text { Gross alpha- and beta-particle } \\
\text { radioactivity }\end{array}$ & $\begin{array}{l}\text { Polyethylene, } \\
\text { acid-rinsed }\end{array}$ & IL & $\mathrm{HNO}_{3}$ & $20 \mathrm{~mL}$ & Filter \\
\hline Strontium-90 & $\begin{array}{l}\text { Polyethylene, } \\
\text { acid-rinsed }\end{array}$ & IL & $\mathrm{HNO}_{3}$ & $20 \mathrm{~mL}$ & Filter \\
\hline Tritium & $\begin{array}{l}\text { Polyethylene or } \\
\text { glass, baked }\end{array}$ & $500 \mathrm{~mL}$ & None & None & None \\
\hline
\end{tabular}




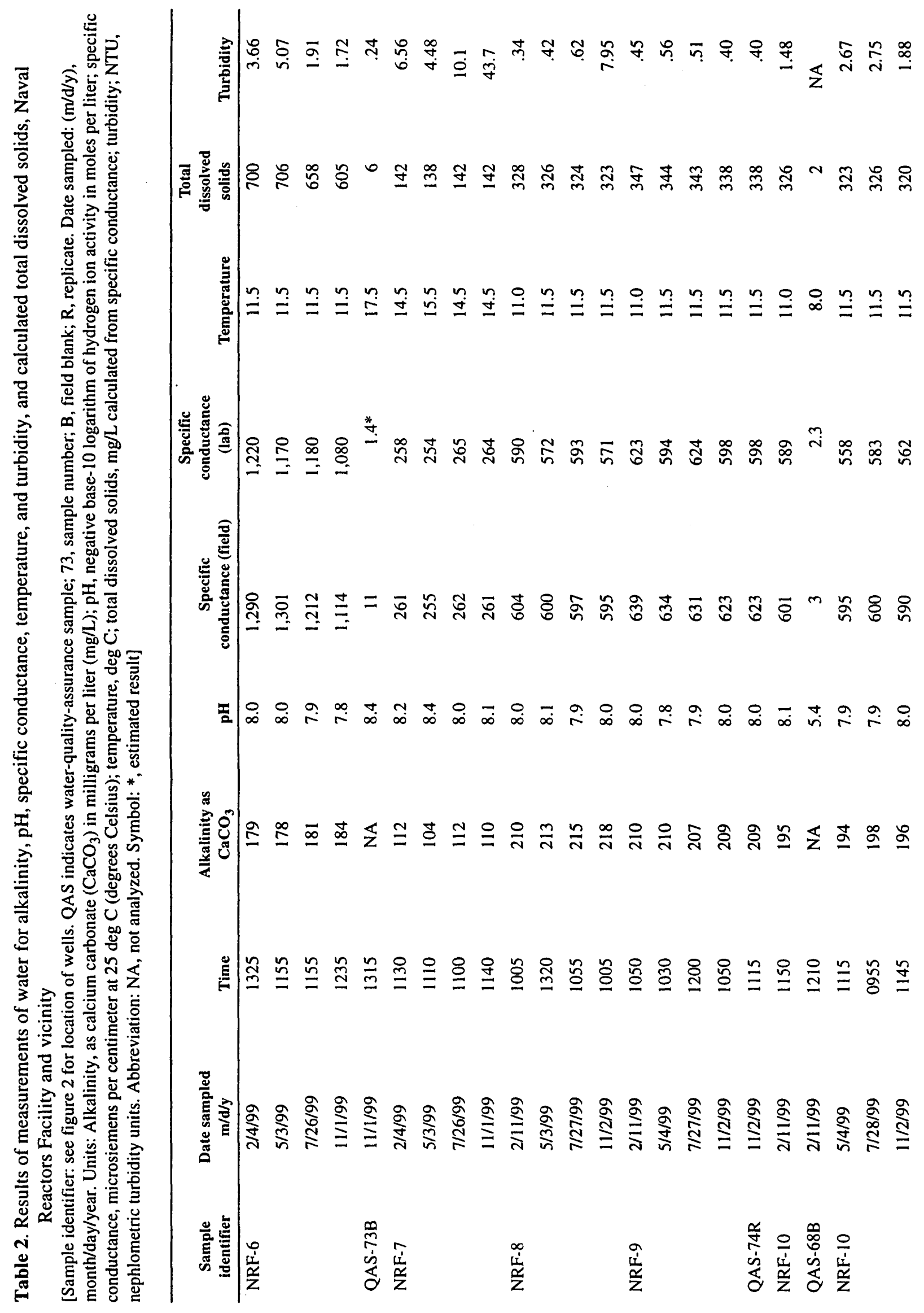




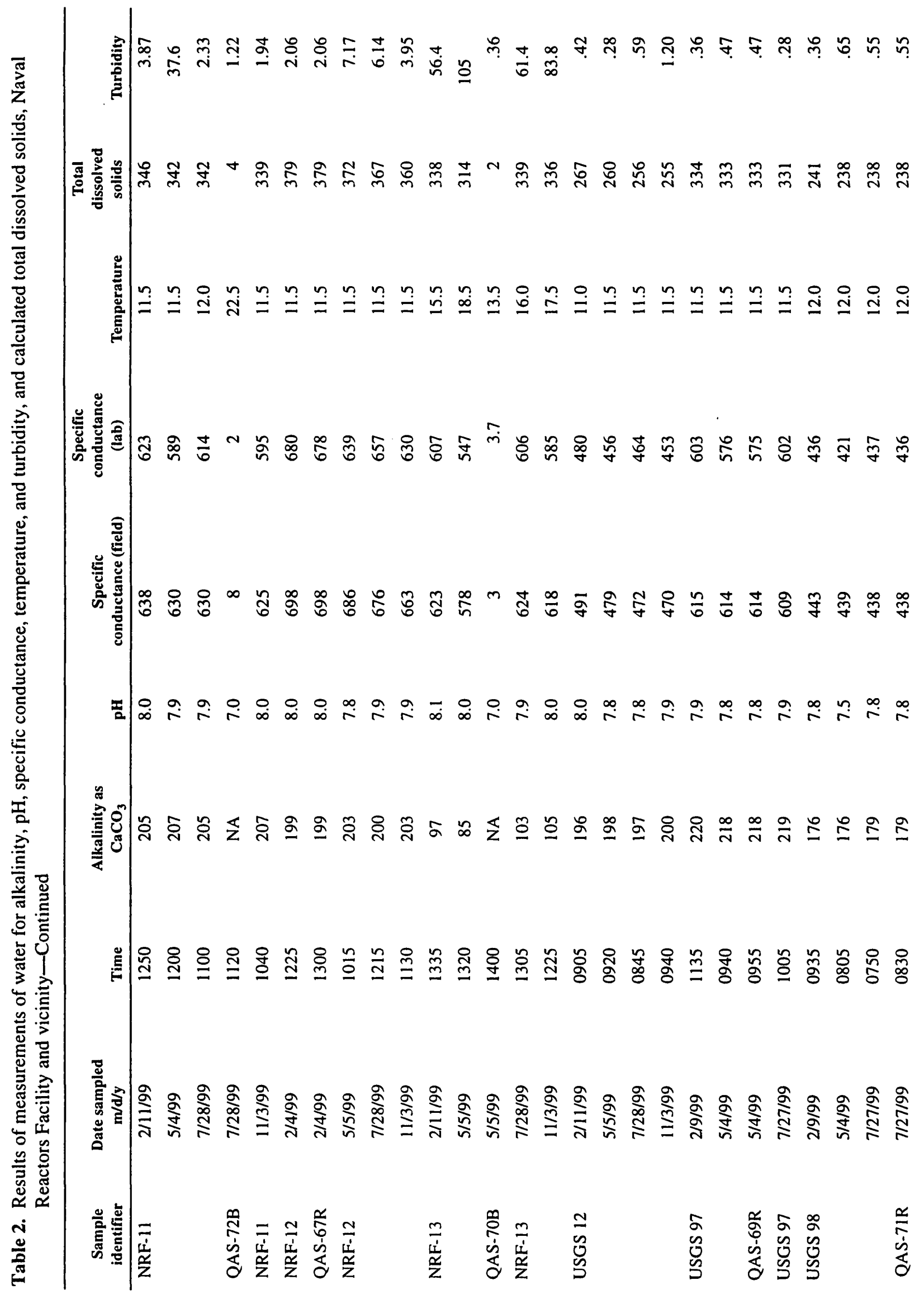




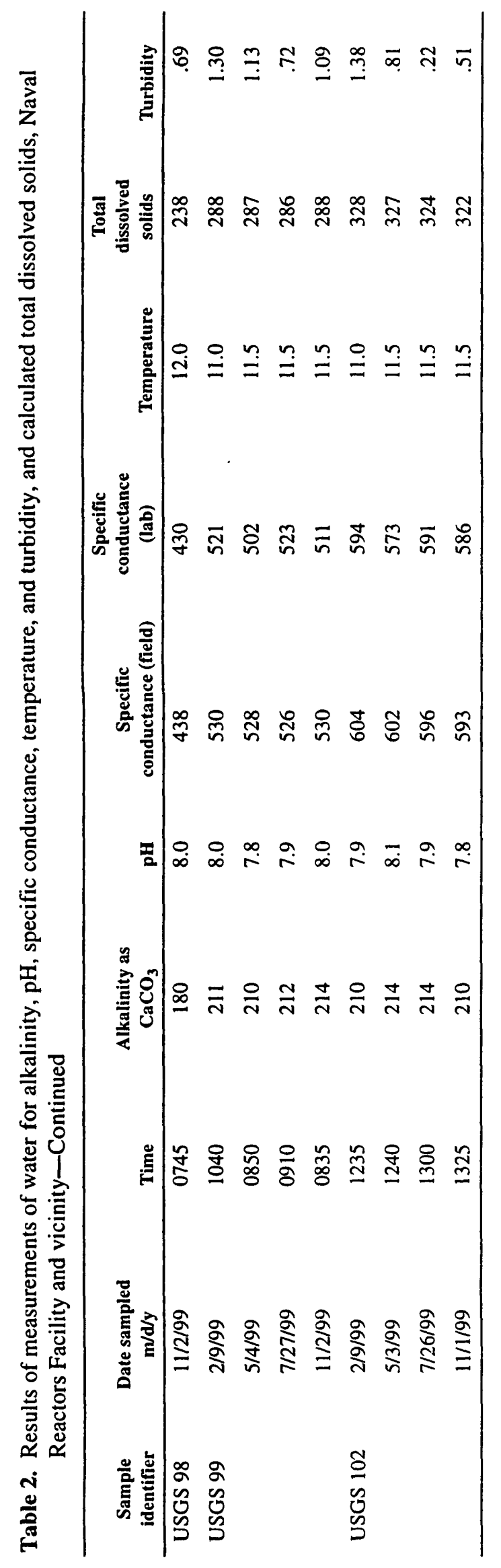


Table 3. Concentrations of dissolved anions and total cations in water, Naval Reactors Facility and vicinity [Analyses were performed by Quanterra Laboratory. Analytical results in milligrams per liter. Sample identifier: see figure 2 for location of wells. QAS indicates water-quality-assurance sample; 73, sample number; B, field blank; R, replicate. Date sampled: $(\mathrm{m} / \mathrm{d} / \mathrm{y})$, month/day/year. Abbreviations: $\mathrm{Q}$, reporting limit was elevated because of large analyte values; ND, not detected. Symbol: *, estimated concentration]

\begin{tabular}{|c|c|c|c|c|c|c|c|}
\hline $\begin{array}{c}\text { Sample } \\
\text { identifier }\end{array}$ & $\begin{array}{l}\text { Date sampled } \\
\mathbf{m} / \mathbf{d} / \mathbf{y}\end{array}$ & $\underset{\text { (total) }}{\text { Calcium }}$ & $\begin{array}{l}\text { Chloride } \\
\text { (dissolved) }\end{array}$ & $\begin{array}{l}\text { Magnesium } \\
\text { (total) }\end{array}$ & $\begin{array}{l}\text { Potassium } \\
\quad \text { (total) }\end{array}$ & $\begin{array}{l}\text { Sodium } \\
\text { (total) }\end{array}$ & $\begin{array}{c}\text { Sulfate } \\
\text { (dissolved) }\end{array}$ \\
\hline \multirow[t]{4}{*}{ NRF-6 } & $2 / 4 / 99$ & 114 & $199 \mathrm{Q}$ & 29.3 & $4.5^{*}$ & 93.6 & $138 \mathrm{Q}$ \\
\hline & $5 / 3 / 99$ & 117 & $228 \mathrm{Q}$ & 30.4 & $4.7^{*}$ & 95.6 & $131 Q$ \\
\hline & $7 / 26 / 99$ & 111 & 191Q & 28.8 & $4.3^{*}$ & 83.9 & $128 \mathrm{Q}$ \\
\hline & $11 / 1 / 99$ & 96.3 & $176 \mathrm{Q}$ & 26.5 & $3.7^{*}$ & 77.2 & $113 Q$ \\
\hline QAS-73B & $11 / 1 / 99$ & $.015^{*}$ & ND & ND & ND & $.60 *$ & ND \\
\hline \multirow[t]{4}{*}{ NRF-7 } & $2 / 4 / 99$ & 27.1 & 5.1 & 9.5 & $3.0^{*}$ & 8.7 & 13.2 \\
\hline & $5 / 3 / 99$ & 27.7 & 5.3 & 9.7 & $3.2^{*}$ & 9.5 & 13.3 \\
\hline & $7 / 26 / 99$ & 30.0 & 5.3 & 9.8 & $2.9^{*}$ & 8.2 & 14.0 \\
\hline & $11 / 1 / 99$ & 28.3 & 5.8 & 9.8 & $3.0^{*}$ & 8.9 & 14.2 \\
\hline \multirow[t]{4}{*}{ NRF-8 } & $2 / 11 / 99$ & 70.5 & 36.5 & 22.3 & $2.4^{*}$ & 14.5 & 34.7 \\
\hline & $5 / 3 / 99$ & 71.5 & 39.8 & 23.1 & $2.5^{*}$ & 14.6 & 34.6 \\
\hline & 7/27/99 & 71.6 & 36.4 & 23.1 & $2.2^{*}$ & 15.6 & 35.5 \\
\hline & $11 / 2 / 99$ & 66.7 & 41.7 & 22.9 & $2.3^{*}$ & 15.2 & 36.2 \\
\hline \multirow[t]{4}{*}{ NRF-9 } & $2 / 11 / 99$ & 74.9 & 45.6 & 23.0 & $2.2^{*}$ & 17.2 & 42.8 \\
\hline & $5 / 4 / 99$ & 75.3 & 49.5 & 23.3 & $2.4^{*}$ & 18.0 & 42.7 \\
\hline & 7/27/99 & 74.7 & 45.1 & 23.4 & $2.2^{*}$ & 17.6 & 43.1 \\
\hline & $11 / 2 / 99$ & 68.7 & 49.3 & 22.7 & $2.4^{*}$ & 16.9 & 42.4 \\
\hline QAS-74R & $11 / 2 / 99$ & 71.0 & 49.9 & 23.2 & $2.4^{*}$ & 16.7 & 42.6 \\
\hline NRF-10 & $2 / 11 / 99$ & 68.7 & 42.2 & 21.7 & $2.6^{*}$ & 14.4 & 39.9 \\
\hline QAS-68B & $2 / 11 / 99$ & ND & ND & ND & ND & ND & ND \\
\hline \multirow[t]{3}{*}{ NRF-10 } & $5 / 4 / 99$ & 70.5 & 45.7 & 22.7 & $2.8^{*}$ & 14.5 & 39.5 \\
\hline & $7 / 28 / 99$ & 71.1 & 41.7 & 23.0 & $2.4^{*}$ & 16.2 & 39.9 \\
\hline & $11 / 2 / 99$ & 66.9 & 50.0 & 22.6 & $2.4^{*}$ & 15.2 & 40.8 \\
\hline \multirow[t]{3}{*}{ NRF-11 } & $2 / 11 / 99$ & 73.6 & 46.6 & 22.9 & $2.4^{*}$ & 16.8 & 41.9 \\
\hline & $5 / 4 / 99$ & 74.1 & $44.5 \mathrm{Q}$ & 23.4 & $2.5^{*}$ & 17.3 & 41.4 \\
\hline & $7 / 28 / 99$ & 69.1 & 47.2 & 21.9 & $2.5^{*}$ & 18.5 & 42.3 \\
\hline
\end{tabular}


Table 3. Concentrations of dissolved anions and total cations in water, Naval Reactors Facility and vicinityContinued

\begin{tabular}{|c|c|c|c|c|c|c|c|}
\hline $\begin{array}{c}\text { Sample } \\
\text { identifier }\end{array}$ & $\begin{array}{l}\text { Date sampled } \\
\mathbf{m} / \mathbf{d} / \mathbf{y}\end{array}$ & $\begin{array}{c}\text { Calcium } \\
\text { (total) }\end{array}$ & $\begin{array}{l}\text { Chloride } \\
\text { (dissolved) }\end{array}$ & $\begin{array}{l}\text { Magnesium } \\
\text { (total) }\end{array}$ & $\begin{array}{l}\text { Potassium } \\
\text { (total) }\end{array}$ & $\begin{array}{l}\text { Sodium } \\
\text { (total) }\end{array}$ & $\begin{array}{c}\text { Sulfate } \\
\text { (dissolved) }\end{array}$ \\
\hline QAS-72B & 7/28/99 & $.07^{*}$ & ND & $.02 *$ & ND & ND & ND \\
\hline NRF-11 & $11 / 3 / 99$ & 73.2 & 47.1Q & 23.5 & $2.8^{*}$ & 19.5 & 42.2 \\
\hline NRF-12 & $2 / 4 / 99$ & 77.1 & $56.0 \mathrm{Q}$ & 23.6 & $2.9^{*}$ & 23.5 & $48.9 \mathrm{Q}$ \\
\hline QAS-67R & $2 / 4 / 99$ & 78.2 & $55.6 \mathrm{Q}$ & 24.0 & $2.7^{*}$ & 23.7 & $49.0 \mathrm{Q}$ \\
\hline \multirow[t]{3}{*}{ NRF-12 } & $5 / 5 / 99$ & 79.2 & $59.1 \mathrm{Q}$ & 24.4 & $3.1^{*}$ & 25.2 & $47.8 Q$ \\
\hline & $7 / 28 / 99$ & 76.3 & $53.4 \mathrm{Q}$ & 23.8 & $2.5^{*}$ & 23.7 & $48.4 \mathrm{Q}$ \\
\hline & $11 / 3 / 99$ & 76.0 & $55.9 \mathrm{Q}$ & 24.1 & $2.6^{*}$ & 23.3 & 49.7 \\
\hline \multirow[t]{2}{*}{ NRF-13 } & $2 / 11 / 99$ & 71.1 & $69.0 \mathrm{Q}$ & 20.4 & $3.9^{*}$ & 9.6 & 82.1 \\
\hline & 5/5/99 & 74.0 & $69.6 \mathrm{Q}$ & 20.5 & $4.1^{*}$ & 11.2 & $75.6 \mathrm{Q}$ \\
\hline QAS-70B & $5 / 5 / 99$ & $.064^{*}$ & ND & $.014^{*}$ & ND & ND & ND \\
\hline \multirow[t]{2}{*}{ NRF-13 } & $7 / 28 / 99$ & 78.1 & $69.0 \mathrm{Q}$ & 24.1 & $3.9^{*}$ & 11.9 & $81.0 \mathrm{Q}$ \\
\hline & $11 / 3 / 99$ & 73.9 & $81.2 \mathrm{Q}$ & 21.9 & $4.0^{*}$ & 12.3 & $86.9 \mathrm{Q}$ \\
\hline \multirow[t]{4}{*}{ USGS 12} & $2 / 11 / 99$ & 56.0 & 17.4 & 17.7 & $1.9^{*}$ & 13.3 & 24.3 \\
\hline & $5 / 5 / 99$ & 58.7 & 17.3 & 18.6 & $2.2^{*}$ & 13.4 & 23.2 \\
\hline & $7 / 28 / 99$ & .57 .5 & 14.9 & 18.4 & $1.7^{*}$ & 13.3 & 23.9 \\
\hline & $11 / 3 / 99$ & 57.3 & 15.8 & 18.6 & $1.8^{*}$ & 13.1 & 24.0 \\
\hline \multirow[t]{2}{*}{ USGS 97} & 2/9/99 & 71.3 & 14.4 & 23.3 & $1.9^{*}$ & 16.9 & 21.4 \\
\hline & $5 / 4 / 99$ & 73.7 & 40.0 & 24.0 & $2.1^{*}$ & 15.8 & 34.4 \\
\hline QAS-69R & $5 / 4 / 99$ & 72.8 & 40.2 & 23.7 & $2.2^{*}$ & 15.3 & 34.6 \\
\hline \multirow[t]{2}{*}{ USGS 97} & 7/27/99 & 71.6 & 36.8 & 23.6 & $2.1^{*}$ & 16.6 & 35.4 \\
\hline & $11 / 2 / 99$ & 66.6 & 41.6 & 23.0 & $1.9^{*}$ & 15.7 & 35.6 \\
\hline \multirow[t]{3}{*}{ USGS 98} & $2 / 9 / 99$ & 50.9 & 14.4 & 19.3 & $2.0^{*}$ & 10.1 & 21.6 \\
\hline & $5 / 4 / 99$ & 51.3 & 15.4 & 19.4 & $2.3^{*}$ & 10.2 & 21.3 \\
\hline & 7/27/99 & 51.1 & 14.5 & 19.5 & $2.0^{*}$ & 10.7 & 22.1 \\
\hline QAS-71R & 7/27/99 & 50.4 & 14.4 & 19.2 & $1.6^{*}$ & 8.8 & 22.0 \\
\hline USGS 98 & $11 / 2 / 99$ & 46.7 & 16.7 & 18.8 & $2.1 *$ & 9.1 & 22.6 \\
\hline \multirow[t]{2}{*}{ USGS 99} & $2 / 9 / 99$ & 62.5 & 20.5 & 21.8 & $1.6^{*}$ & 15.4 & 25.2 \\
\hline & $5 / 4 / 99$ & 62.9 & 22.4 & 21.9 & $1.9^{*}$ & 14.9 & 24.9 \\
\hline
\end{tabular}


Table 3. Concentrations of dissolved anions and total cations in water, Naval Reactors Facility and vicinityContinued

\begin{tabular}{cccccccc}
\hline $\begin{array}{c}\text { Sample } \\
\text { identifier }\end{array}$ & $\begin{array}{c}\text { Date sampled } \\
\mathbf{m} / \mathbf{d} / \mathbf{y}\end{array}$ & $\begin{array}{c}\text { Calcium } \\
\text { (total) }\end{array}$ & $\begin{array}{c}\text { Chloride } \\
\text { (dissolved) }\end{array}$ & $\begin{array}{c}\text { Magnesium } \\
\text { (total) }\end{array}$ & $\begin{array}{c}\text { Potassium } \\
\text { (total) }\end{array}$ & $\begin{array}{c}\text { Sodium } \\
\text { (total) }\end{array}$ & $\begin{array}{c}\text { Sulfate } \\
\text { (dissolved) }\end{array}$ \\
\hline USGS 99 & $7 / 27 / 99$ & 61.3 & 20.8 & 21.5 & $1.7^{*}$ & 14.4 & 25.9 \\
& $11 / 2 / 99$ & 57.1 & 24.0 & 21.2 & $1.6^{*}$ & 13.4 & 26.5 \\
USGS 102 & $2 / 9 / 99$ & 71.9 & 36.0 & 23.0 & $2.2^{*}$ & 16.3 & 34.4 \\
& $5 / 3 / 99$ & 71.7 & 39.5 & 23.4 & $2.4^{*}$ & 15.7 & 34.3 \\
& $7 / 26 / 99$ & 73.1 & 36.2 & 23.6 & $2.0^{*}$ & 14.0 & 35.1 \\
& $11 / 1 / 99$ & 65.7 & 41.2 & 22.4 & $2.4 *$ & 15.5 & 35.7 \\
\hline
\end{tabular}




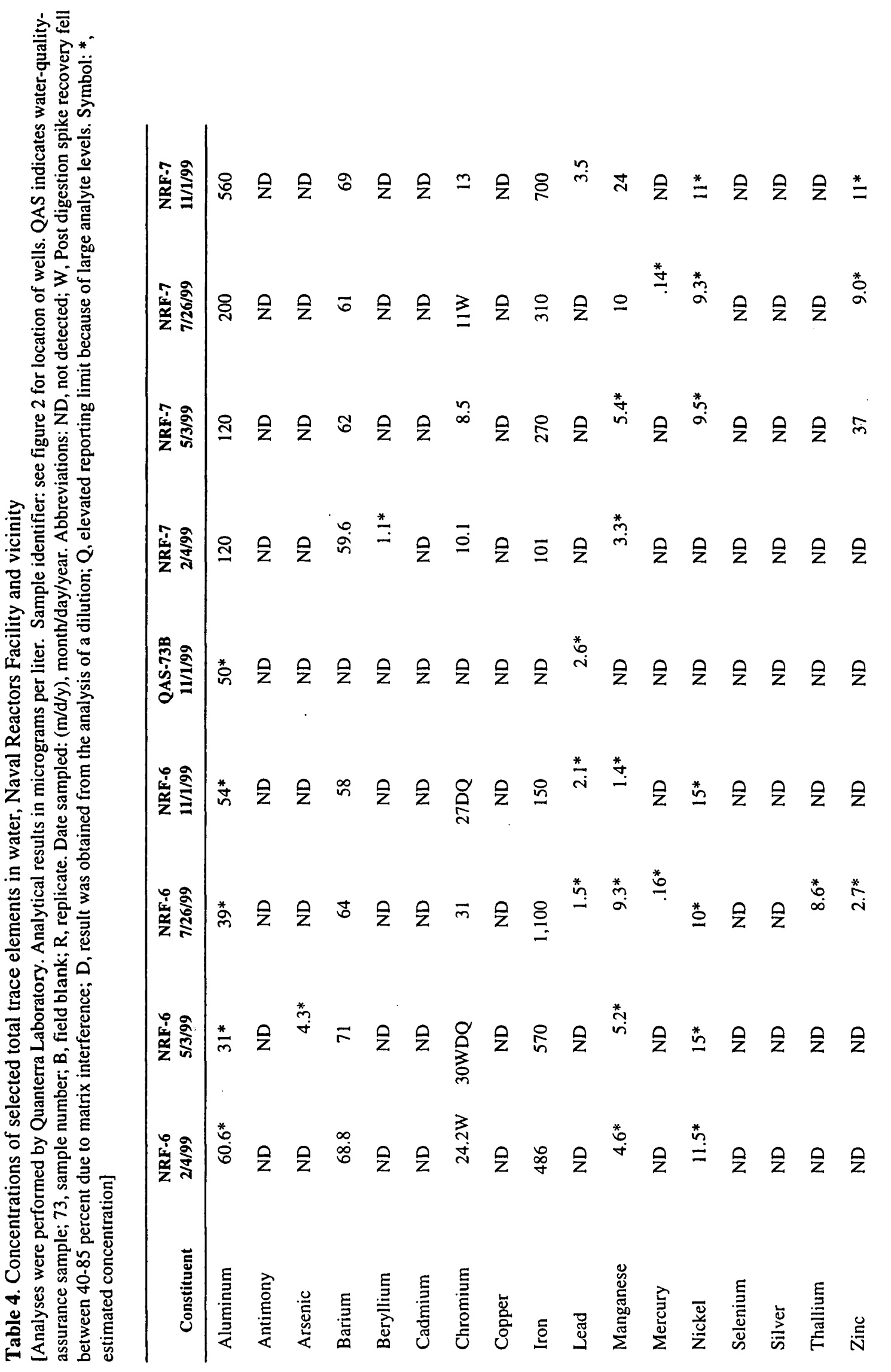




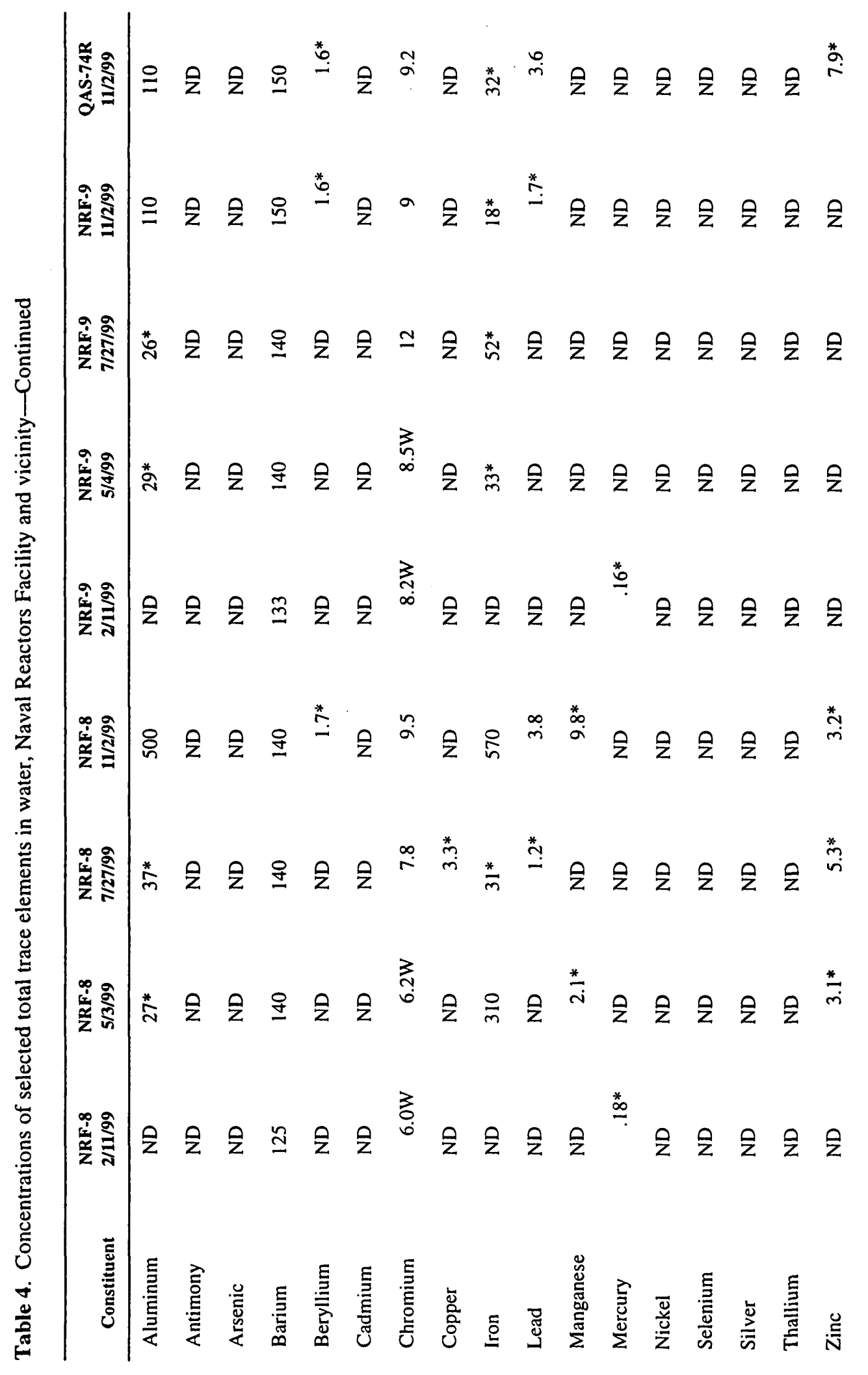




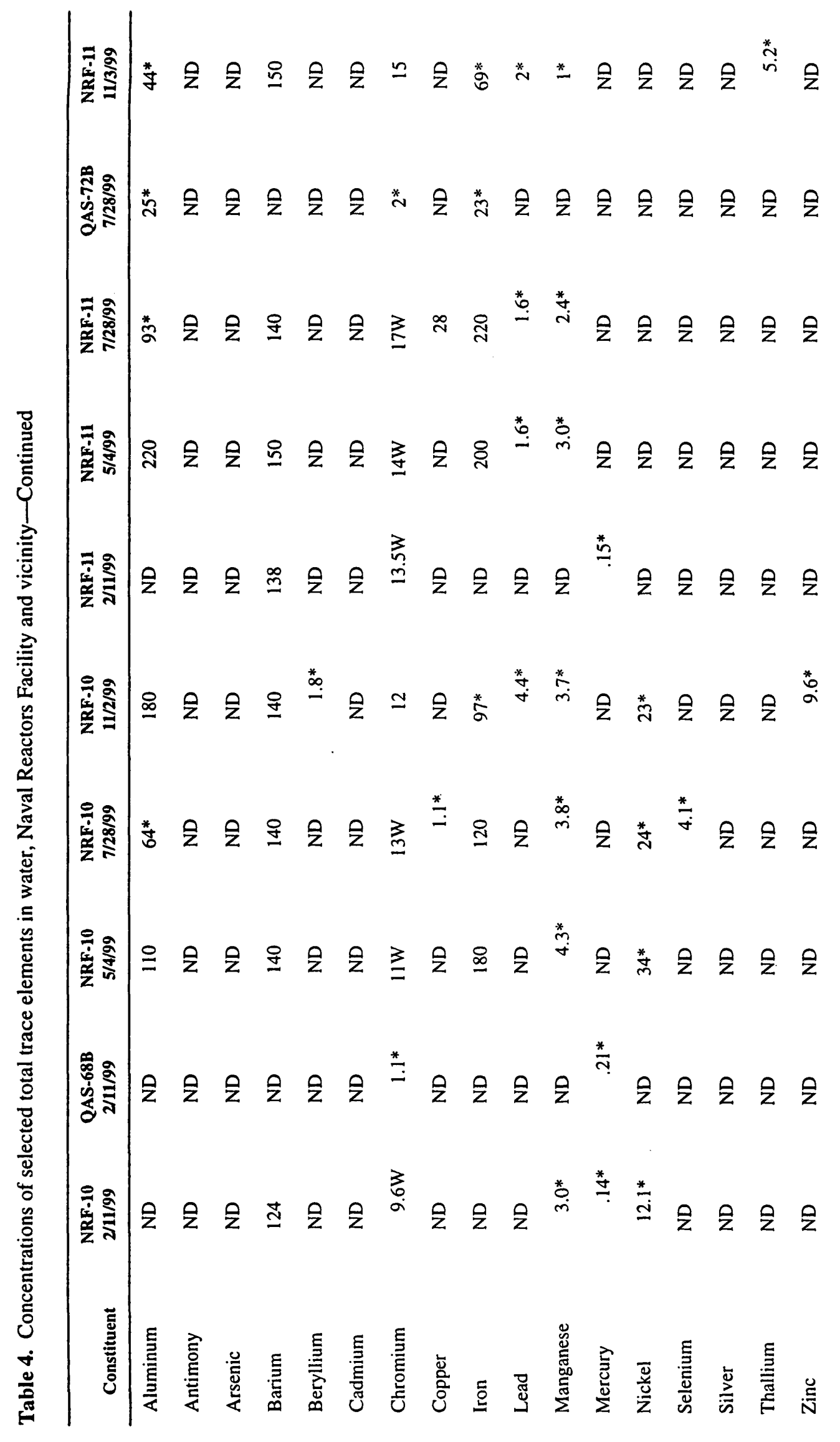




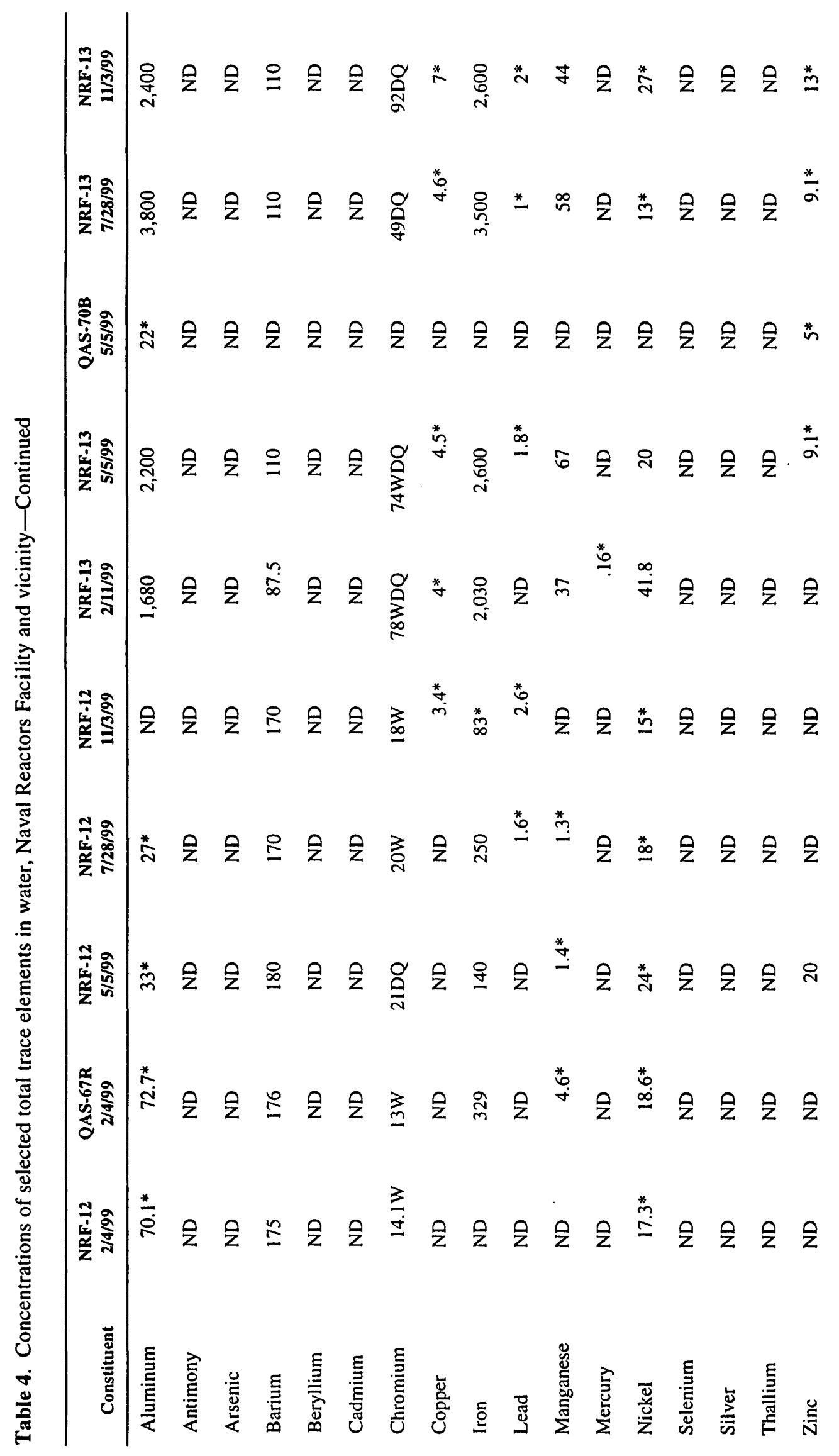




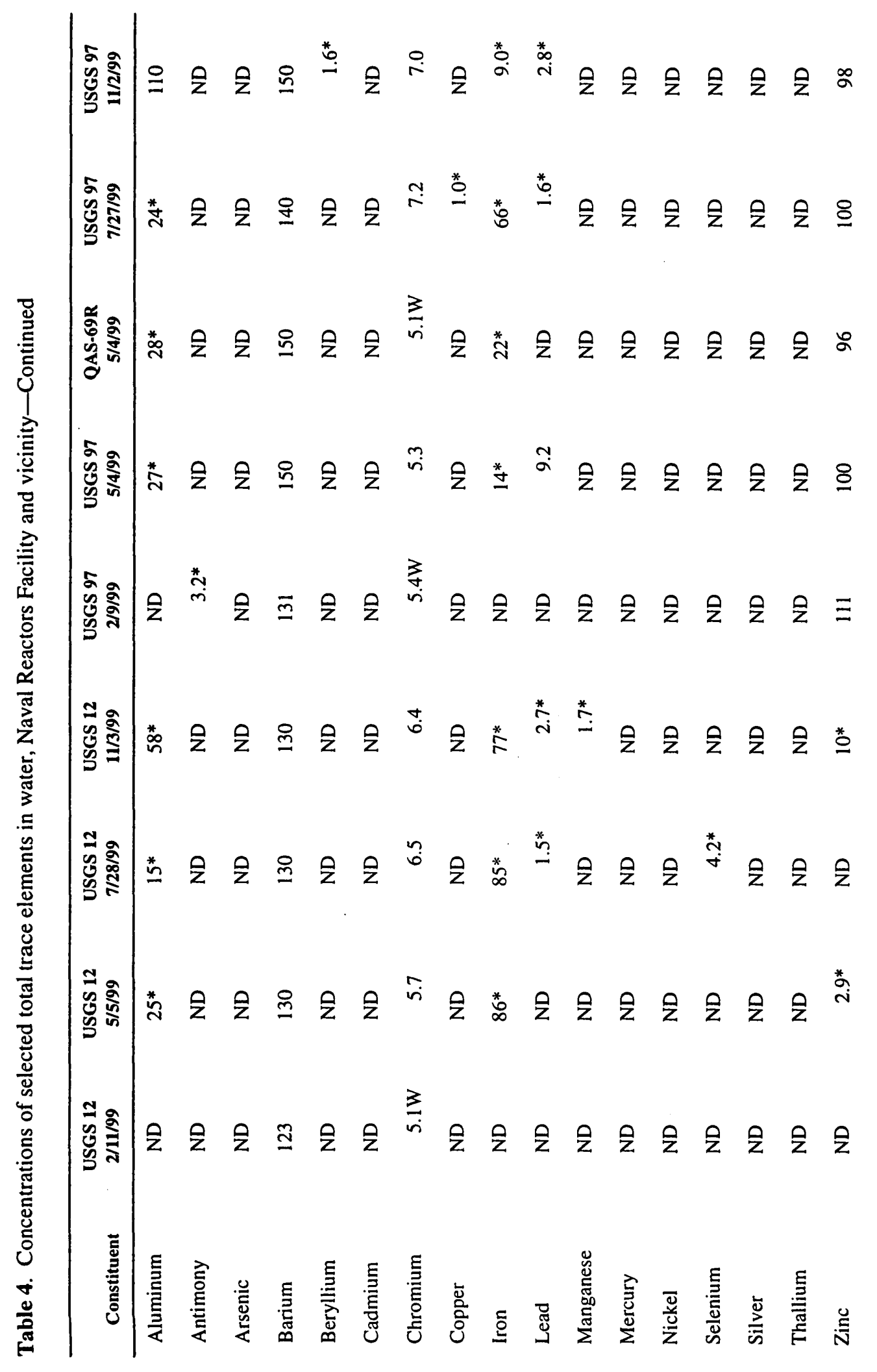




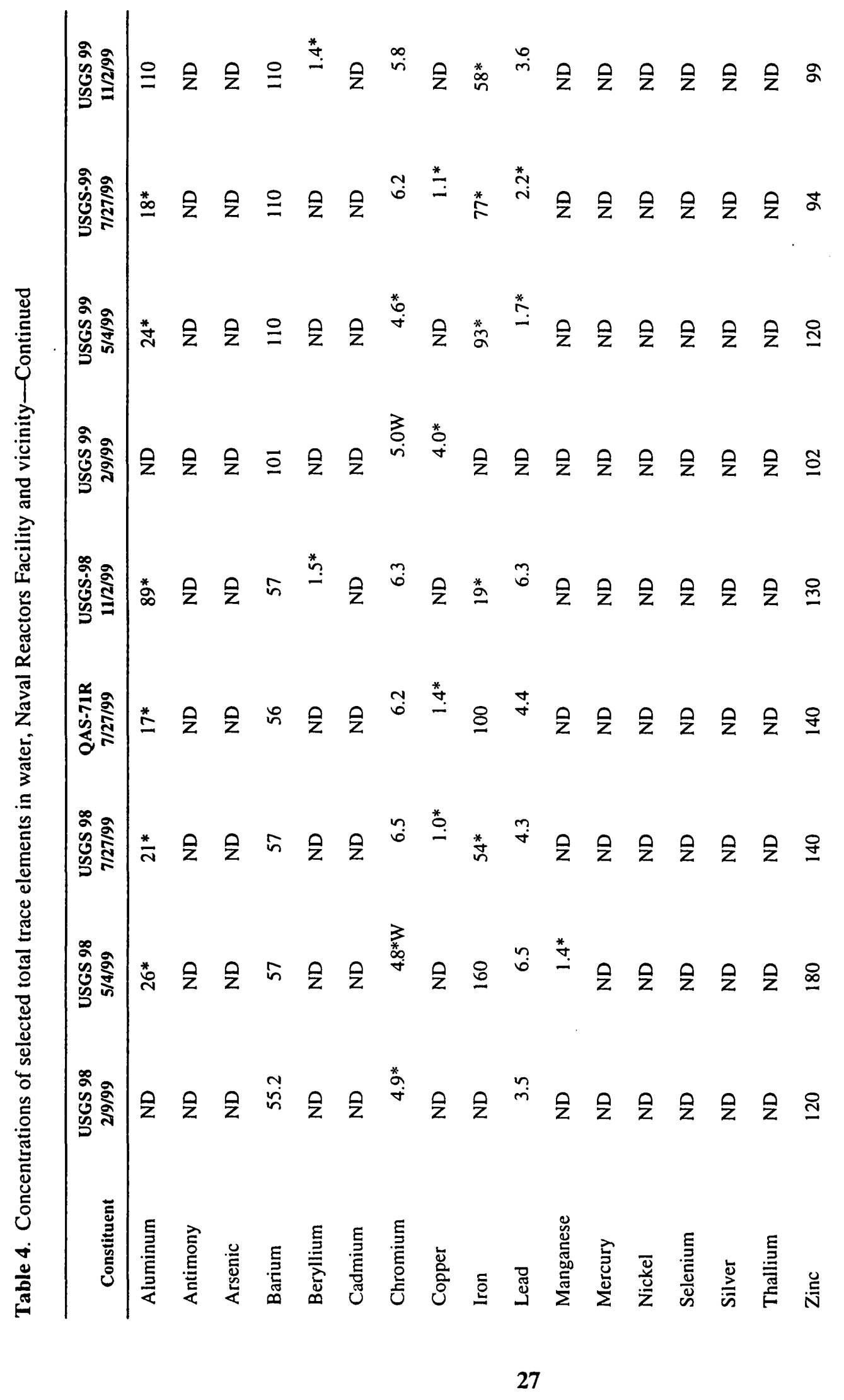


<smiles>CC1=CC=C1</smiles> 
Table 5. Concentrations of dissolved and total nutrients, total organic carbon, and total organic halogens in water, Naval Reactors Facility and vicinity

[Analyses were performed by Quanterra Laboratory. Analytical results in milligrams per liter. Sample identifier: see figure 2 for location of wells. QAS indicates water-quality-assurance sample; 73, sample number; B, field blank; R, replicate. Date sampled: $(\mathrm{m} / \mathrm{d} / \mathrm{y})$, month/day/year. Abbreviations: ND, analysis not detected; $\mathrm{Q}$, reporting limit is elevated because of large analyte values. Symbol: *, indicates estimated result]

\begin{tabular}{|c|c|c|c|c|c|c|c|}
\hline $\begin{array}{c}\text { Sample } \\
\text { identifier }\end{array}$ & $\begin{array}{l}\text { Date sampled } \\
\mathbf{m} / \mathrm{d} / \mathbf{y}\end{array}$ & $\begin{array}{c}\text { Kjeldahl } \\
\text { nitrogen } \\
\text { (total) }\end{array}$ & $\begin{array}{l}\text { Nitrite as } \\
\text { nitrogen } \\
\text { (dissolved) }\end{array}$ & $\begin{array}{c}\text { Nitrite plus } \\
\text { nitrate as } \\
\text { nitrogen } \\
\text { (total) }\end{array}$ & $\begin{array}{l}\text { Phosphorus } \\
\text { as } \\
\text { phosphorus } \\
\text { (total) }\end{array}$ & $\begin{array}{l}\text { Total organic } \\
\text { carbon }\end{array}$ & $\begin{array}{c}\text { Total organic } \\
\text { halogens }\end{array}$ \\
\hline \multirow[t]{4}{*}{ NRF-6 } & 2/4/99 & $0.088^{*}$ & ND & 1.7 & 0.093 & ND & $0.014^{*}$ \\
\hline & $5 / 3 / 99$ & ND & $.007^{*}$ & .47 & ND & $.53^{*}$ & $.012^{*}$ \\
\hline & $7 / 26 / 99$ & $.18^{*}$ & ND & 1.8 & $.045^{*}$ & 1.0 & ND \\
\hline & $11 / 1 / 99$ & ND & ND & 1.8 & $.035^{*}$ & ND & ND \\
\hline QAS-73B & $11 / 1 / 99$ & ND & ND & ND & $.018^{*}$ & ND & ND \\
\hline \multirow[t]{4}{*}{ NRF-7 } & $2 / 4 / 99$ & $.11 *$ & ND & .53 & $.039^{*}$ & ND & ND \\
\hline & $5 / 3 / 99$ & ND & .33 & .66 & ND & ND & ND \\
\hline & $7 / 26 / 99$ & $.12^{*}$ & ND & .47 & $.031^{*}$ & ND & ND \\
\hline & $11 / 1 / 99$ & ND & ND & .47 & $.04 *$ & ND & ND \\
\hline \multirow[t]{4}{*}{ NRF-8 } & $2 / 11 / 99$ & $.1^{*}$ & $.002 *$ & $2.2 Q$ & $.047^{*}$ & ND & ND \\
\hline & $5 / 4 / 99$ & $.34^{*}$ & .011 & 2.2 & ND & $.37^{*}$ & ND \\
\hline & $7 / 27 / 99$ & $.11 *$ & ND & 2.3 & $.035^{*}$ & $.51 *$ & ND \\
\hline & $11 / 2 / 99$ & ND & ND & 2.0 & .057 & ND & ND \\
\hline \multirow[t]{4}{*}{ NRF-9 } & $2 / 11 / 99$ & ND & $.002 *$ & $2.0 \mathrm{Q}$ & .057 & ND & $.010^{*}$ \\
\hline & $5 / 4 / 99$ & ND & ND & 2.3 & ND & $.85 *$ & $.004^{*}$ \\
\hline & 7/27/99 & $.12^{*}$ & ND & 2.3 & $.031^{*}$ & $.49 *$ & ND \\
\hline & $11 / 2 / 99$ & ND & ND & 2.2 & $.041^{*}$ & ND & $.004^{*}$ \\
\hline QAS-74R & $11 / 2 / 99$ & ND & ND & 2.1 & $.029 *$ & $.26^{*}$ & ND \\
\hline NRF-10 & $2 / 11 / 99$ & $.091 *$ & $.002 *$ & $1.8 \mathrm{Q}$ & .058 & ND & ND \\
\hline QAS-68B & $2 / 11 / 99$ & $.36 *$ & $.003 *$ & ND & $.035^{*}$ & ND & ND \\
\hline \multirow[t]{3}{*}{ NRF-10 } & $5 / 4 / 99$ & ND & ND & 1.9 & .084 & $.86^{*}$ & $.004^{*}$ \\
\hline & $7 / 28 / 99$ & ND & ND & 2.1 & $.017^{*}$ & $.95^{*}$ & ND \\
\hline & $11 / 2 / 99$ & ND & ND & 1.8 & $.043^{*}$ & ND & ND \\
\hline
\end{tabular}


Table 5. Concentrations of dissolved and total nutrients, total organic carbon, and total organic halogens in water, Naval Reactors Facility and vicinity - Continued

\begin{tabular}{|c|c|c|c|c|c|c|c|}
\hline $\begin{array}{c}\text { Sample } \\
\text { identifier }\end{array}$ & $\begin{array}{l}\text { Date sampled } \\
\mathbf{m} / \mathbf{d} / \mathbf{y}\end{array}$ & $\begin{array}{c}\text { Kjeldahl } \\
\text { nitrogen } \\
\text { (total) }\end{array}$ & $\begin{array}{l}\text { Nitrite as } \\
\text { nitrogen } \\
\text { (dissolved) }\end{array}$ & $\begin{array}{l}\text { Nitrite plus } \\
\text { nitrate as } \\
\text { nitrogen } \\
\text { (total) }\end{array}$ & $\begin{array}{l}\text { Phosphorus } \\
\text { as } \\
\text { phosphorus } \\
\text { (total) }\end{array}$ & $\begin{array}{l}\text { Total organic } \\
\text { carbon }\end{array}$ & $\begin{array}{c}\text { Total organic } \\
\text { halogens }\end{array}$ \\
\hline \multirow[t]{3}{*}{ NRF-11 } & $2 / 11 / 99$ & $.079^{*}$ & .013 & $2.2 \mathrm{Q}$ & .05 & ND & $.012^{*}$ \\
\hline & $5 / 4 / 99$ & ND & ND & 2.1 & ND & $.98^{*}$ & ND \\
\hline & 7/28/99 & $.41^{*}$ & ND & 2.3 & .053 & $.48^{*}$ & ND \\
\hline QAS-72B & $7 / 28 / 99$ & $.22^{*}$ & ND & ND & $.045^{*}$ & ND & ND \\
\hline NRF-11 & $11 / 3 / 99$ & ND & ND & 2.1 & ND & ND & ND \\
\hline NRF-12 & $2 / 4 / 99$ & ND & ND & 2.1 & $.035^{*}$ & ND & $.008^{*}$ \\
\hline QAS-67R & $2 / 4 / 99$ & $.095^{*}$ & ND & 2.3 & $.044^{*}$ & $.59 *$ & ND \\
\hline \multirow[t]{3}{*}{ NRF-12 } & $5 / 5 / 99$ & ND & ND & 2.1 & ND & $.54^{*}$ & $.005^{*}$ \\
\hline & $7 / 28 / 99$ & ND & ND & 2.1 & $.05^{*}$ & $.38 *$ & ND \\
\hline & $11 / 3 / 99$ & $.099^{*}$ & ND & 2.0 & $.034^{*}$ & ND & ND \\
\hline \multirow[t]{2}{*}{ NRF-13 } & $2 / 11 / 99$ & $.2^{*}$ & $.007 *$ & .91 & .084 & ND & $.013^{*}$ \\
\hline & $5 / 5 / 99$ & $.24^{*}$ & ND & .80 & .12 & $.31^{*}$ & $.008^{*}$ \\
\hline QAS-70B & $5 / 5 / 99$ & ND & ND & ND & ND & ND & ND \\
\hline \multirow[t]{2}{*}{ NRF-13 } & 7/28/99 & ND & ND & .87 & .13 & $.43^{*}$ & ND \\
\hline & $11 / 3 / 99$ & ND & ND & .84 & .085 & ND & $.006^{*}$ \\
\hline \multirow[t]{4}{*}{ USGS 12} & $2 / 11 / 99$ & ND & $.003 *$ & 1.1 & $.048^{*}$ & ND & ND \\
\hline & $5 / 5 / 99$ & $.33^{*}$ & ND & 1.0 & ND & ND & ND \\
\hline & $7 / 28 / 99$ & $.20^{*}$ & $.008^{*}$ & .95 & .053 & $.64^{*}$ & ND \\
\hline & $11 / 3 / 99$ & $.12 *$ & ND & .82 & $.041^{*}$ & ND & ND \\
\hline \multirow[t]{2}{*}{ USGS 97} & 2/9/99 & $.18 *$ & ND & 2.4 & $.049^{*}$ & ND & ND \\
\hline & $5 / 4 / 99$ & ND & ND & 2.2 & ND & $.76^{*}$ & ND \\
\hline QAS-69R & $5 / 4 / 99$ & ND & ND & 2.3 & ND & $.82 *$ & $.003^{*}$ \\
\hline \multirow[t]{2}{*}{ USGS 97} & $7 / 27 / 99$ & ND & ND & 2.3 & $.033^{*}$ & $.31^{*}$ & ND \\
\hline & $11 / 2 / 99$ & ND & ND & 2.2 & $.032^{*}$ & ND & ND \\
\hline
\end{tabular}


Table 5. Concentrations of dissolved and total nutrients, total organic carbon, and total organic halogens in water, Naval Reactors Facility and vicinity-Continued

\begin{tabular}{cccccccc}
\hline $\begin{array}{c}\text { Sample } \\
\text { identifier }\end{array}$ & $\begin{array}{c}\text { Date sampled } \\
\mathbf{m} / \mathrm{d} / \mathrm{y}\end{array}$ & $\begin{array}{c}\text { Kjeldahl } \\
\text { nitrogen } \\
\text { (total) }\end{array}$ & $\begin{array}{c}\text { Nitrite as } \\
\text { nitrogen } \\
\text { (dissolved) }\end{array}$ & $\begin{array}{c}\text { Nitrite plus } \\
\text { nitrate as } \\
\text { nitrogen } \\
\text { (total) }\end{array}$ & $\begin{array}{c}\text { Phosphorus } \\
\text { as } \\
\text { phosphorus } \\
\text { (total) }\end{array}$ & $\begin{array}{c}\text { Total organic } \\
\text { carbon }\end{array}$ & $\begin{array}{c}\text { Total organic } \\
\text { halogens }\end{array}$ \\
\hline USGS 98 & $2 / 9 / 99$ & ND & ND & .96 & $.038^{*}$ & ND & ND \\
& $5 / 4 / 99$ & ND & ND & 1.2 & ND & $.54^{*}$ & $.004^{*}$ \\
QAS-71R & $7 / 27 / 99$ & $.072^{*}$ & ND & 1.2 & $.036^{*}$ & $.65^{*}$ & ND \\
USGS 98 & $7 / 27 / 99$ & $.088^{*}$ & ND & 1.2 & $.028^{*}$ & $.57^{*}$ & ND \\
USGS 99 & $11 / 2 / 99$ & ND & ND & 1.1 & $.027^{*}$ & ND & $.012^{*}$ \\
& $2 / 9 / 99$ & ND & ND & 1.5 & .055 & ND & ND \\
& $5 / 4 / 99$ & ND & ND & 1.7 & ND & $.86^{*}$ & ND \\
& $7 / 27 / 99$ & $.42^{*}$ & ND & 1.7 & $.026^{*}$ & $.89^{*}$ & ND \\
USGS 102 & $11 / 2 / 99$ & ND & ND & 1.6 & $.044^{*}$ & ND & ND \\
& $2 / 9 / 99$ & ND & ND & 2.4 & .053 & ND & $.0091^{*}$ \\
& $5 / 3 / 99$ & $.076^{*}$ & .012 & 1.9 & ND & $.36^{*}$ & $.003^{*}$ \\
& $7 / 26 / 99$ & $.15 *$ & ND & 2.1 & $.03 *$ & $.48^{*}$ & ND \\
& $11 / 1 / 99$ & .89 & ND & 2.1 & $.027^{*}$ & $.57^{*}$ & ND \\
\hline
\end{tabular}




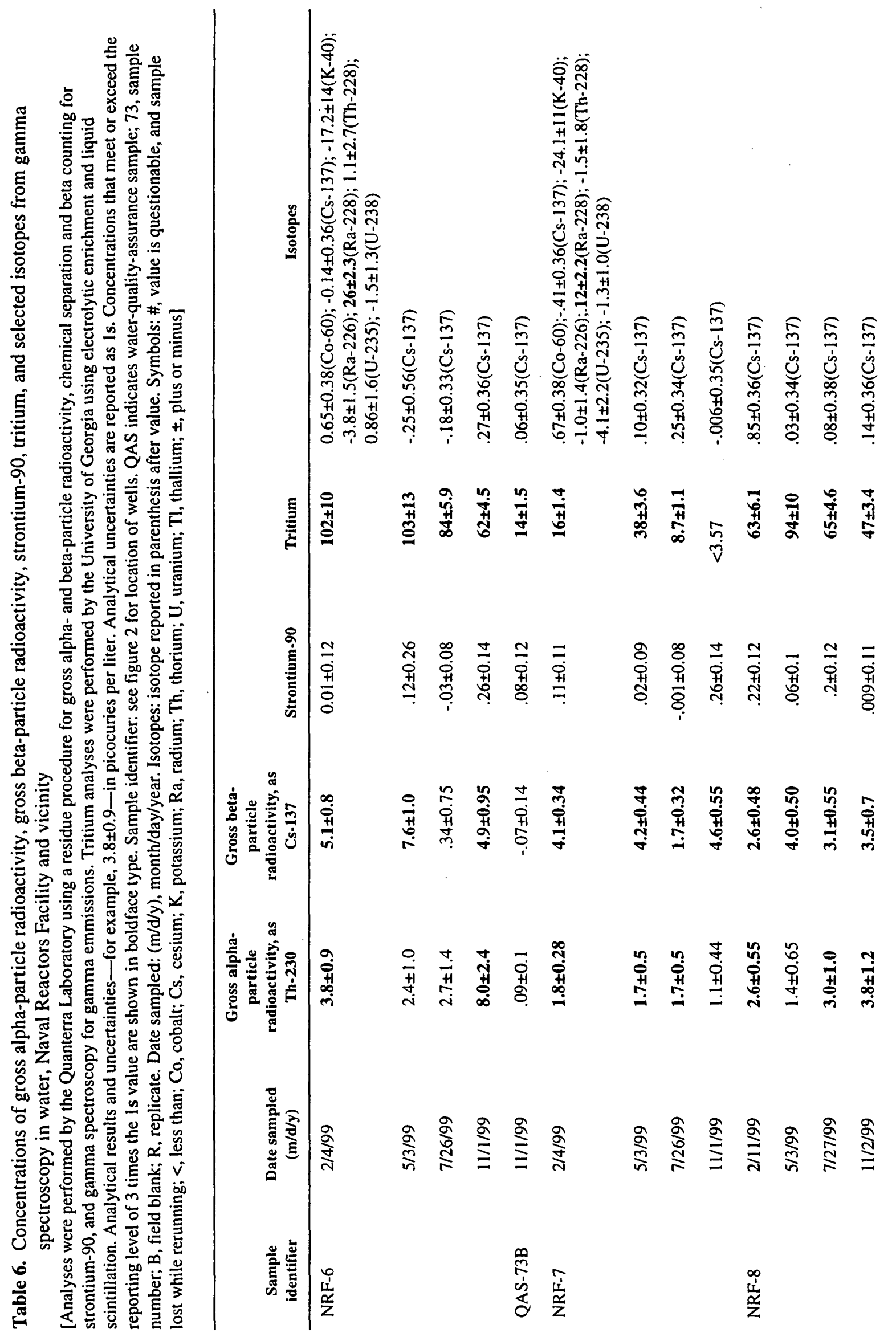




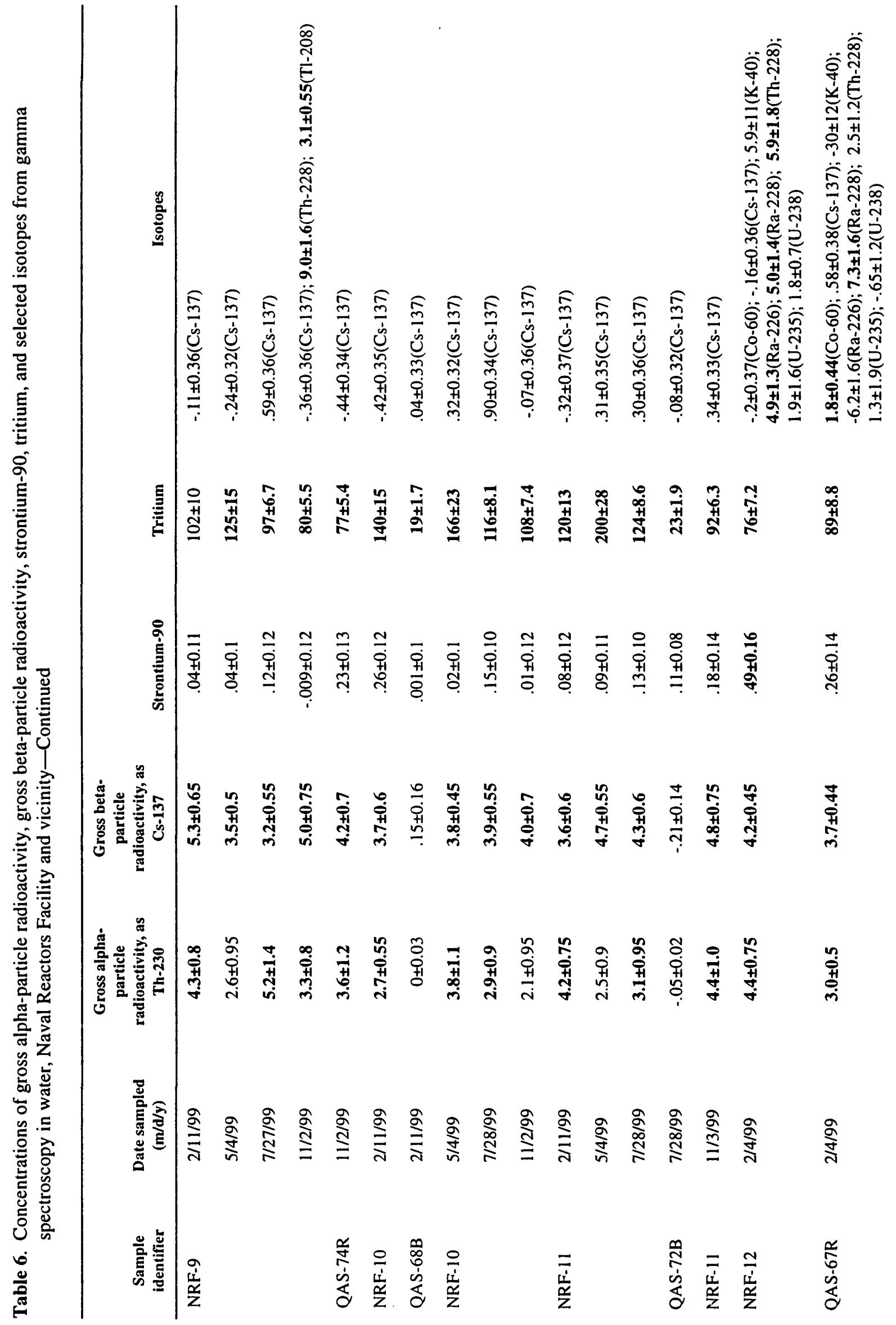




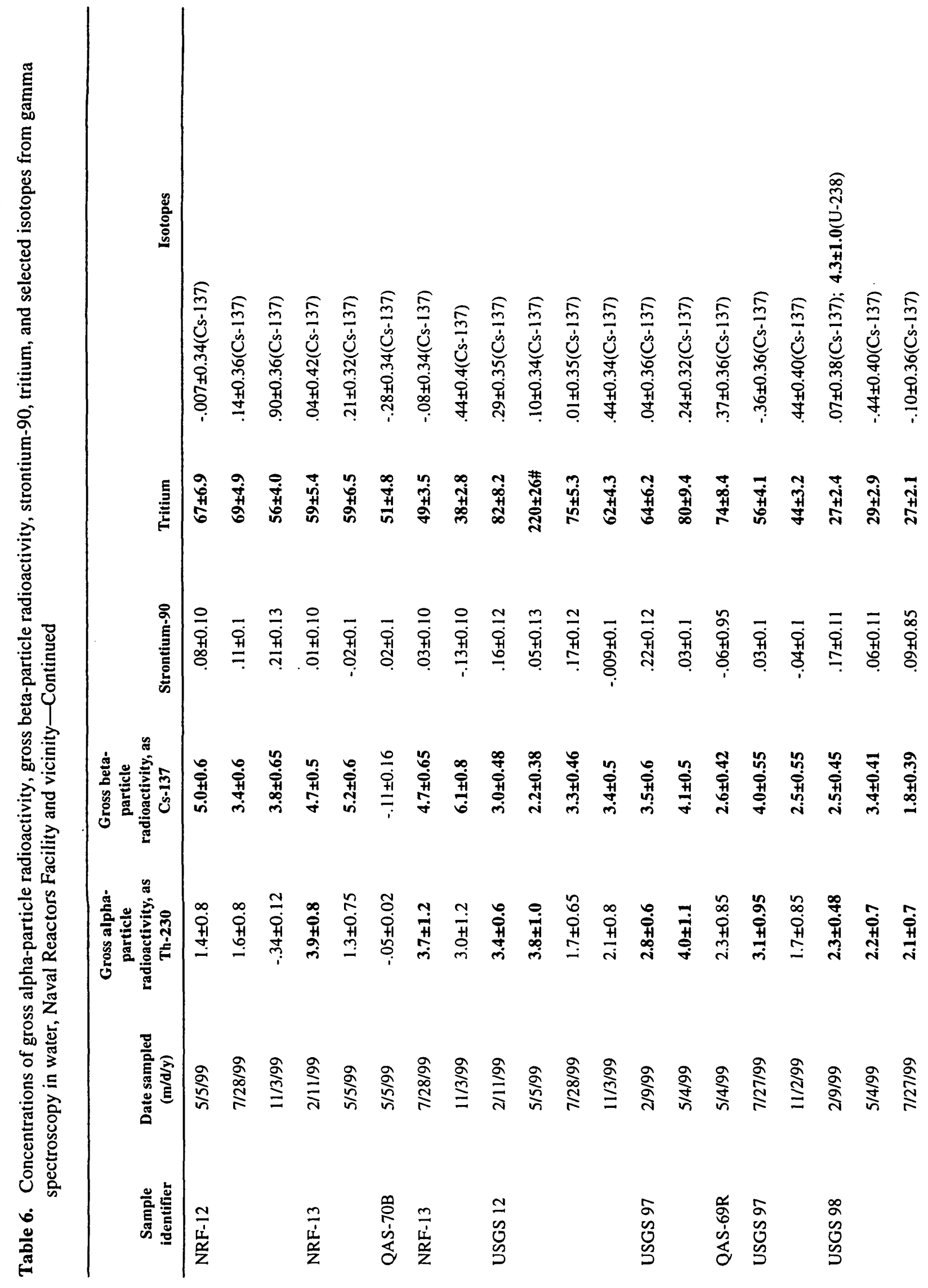




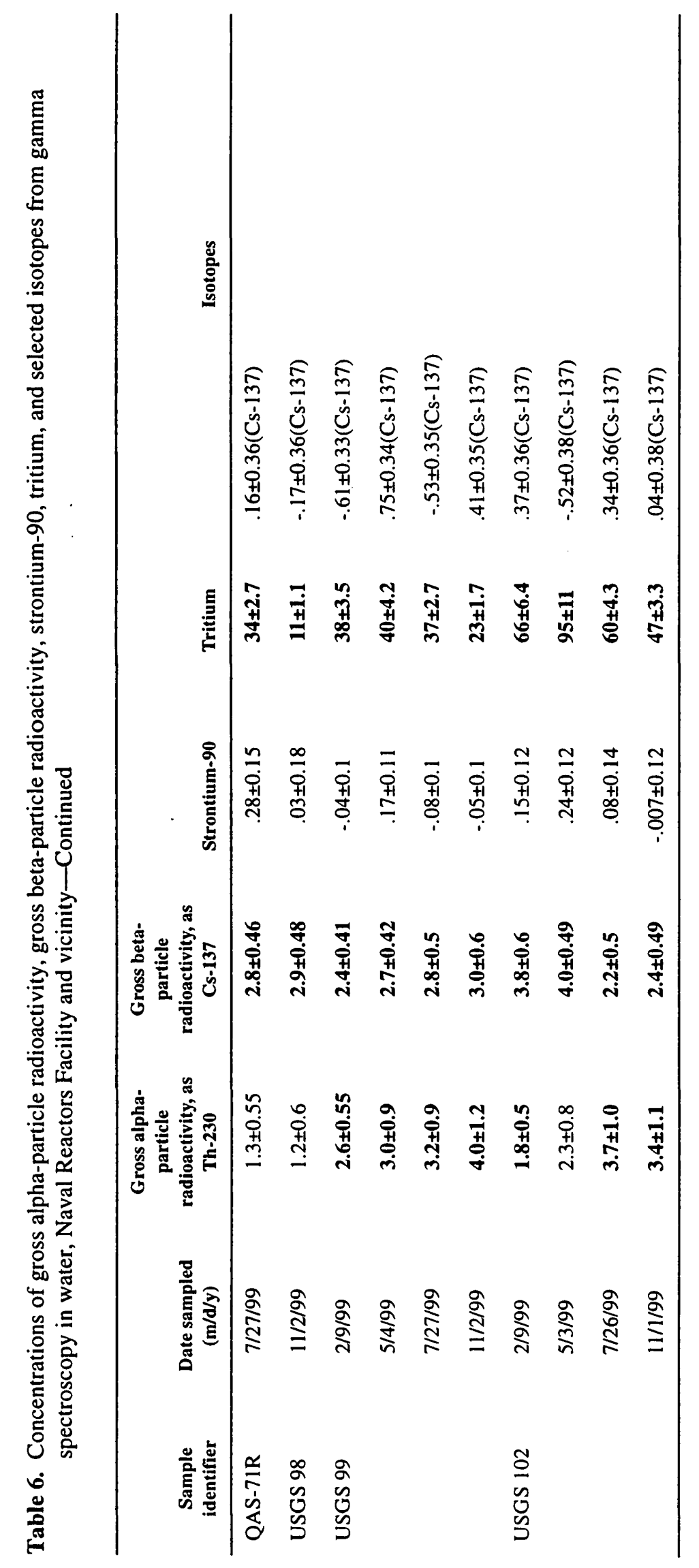


Table 7. Regulatory volatile organic compounds for which water samples were analyzed [Analyses were performed by the Quanterra Laboratory using U.S. Environmental Protection Agency method 524.2. Reporting limits are in micrograms per liter]

\begin{tabular}{|c|c|c|c|}
\hline Compound & $\begin{array}{c}\text { Reporting } \\
\text { limit }\end{array}$ & Compound & $\begin{array}{c}\text { Reporting } \\
\text { limit }\end{array}$ \\
\hline Benzene & 0.5 & 1,2-Dichloropropane & 0.1 \\
\hline Bromobenzene & .2 & 1,3-Dichloropropane & .1 \\
\hline Bromochloromethane & .2 & 2,2-Dichloropropane & .5 \\
\hline Bromodichloromethane & .1 & 1,1-Dichloropropylene & .1 \\
\hline Bromoform & .1 & cis-1,3-Dichloropropylene & .1 \\
\hline Bromomethane & .5 & trans-1,3-Dichloropropylene & .1 \\
\hline n-Butylbenzene & .2 & Ethylbenzene & .1 \\
\hline sec-Butylbenzene & .2 & Hexachlorobutadiene & .2 \\
\hline tert-Butylbenzene & .2 & Isopropylbenzene & .1 \\
\hline Carbon tetrachloride & .1 & 4-Isopropyltoluene & .1 \\
\hline Chlorobenzene & .2 & Methyl-t-butyl ether (MTBE) & .5 \\
\hline Chloroethane & .5 & Naphthalene & .2 \\
\hline Chloroform & .1 & n-Propylbenzene & .1 \\
\hline Chloromethane & .5 & Styrene & .2 \\
\hline 2-Chlorotoluene & .2 & 1,1,1,2-Tetrachloroethane & .1 \\
\hline 4-Chlorotoluene & .2 & 1,1,2,2-Tetrachloroethane & .1 \\
\hline Dibromochloromethane & .1 & Tetrachloroethylene & .2 \\
\hline $\begin{array}{l}\text { 1,2-Dibromo-3-chloropropane } \\
\text { (DBCP) }\end{array}$ & .2 & Toluene & .5 \\
\hline 1,2-Dibromoethane (EDB) & .1 & 1,2,3-Trichlorobenzene & .2 \\
\hline Dibromomethane & .1 & 1,2,4-Trichlorobenzene & .2 \\
\hline 1,2-Dichlorobenzene & .1 & 1,1,1-Trichloroethane & .1 \\
\hline 1,3-Dichlorobenzene & .1 & 1,1,2-Trichloroethane & .1 \\
\hline 1,4-Dichlorobenzene & .1 & Trichloroethylene & .1 \\
\hline Dichlorodifluoromethane & .5 & Trichlorofluoromethane & .5 \\
\hline 1,1-Dichloroethane & .1 & 1,2,3,-Trichloropropane & .2 \\
\hline 1,2-Dichloroethane & .1 & 1,2,4-Trimethylbenzene & .1 \\
\hline 1,1-Dichloroethylhene & .2 & 1,3,5-Trimethylbenzene & .1 \\
\hline cis-1,2-Dichloroethylene & .1 & Vinyl chloride & .2 \\
\hline trans-1,2-Dichloroethylene & .1 & Xylenes (total) & .2 \\
\hline Dichloromethane & .5 & & \\
\hline
\end{tabular}


Table 8. Base/neutral organic compounds for which water samples were analyzed

[Analyses were performed by the Quanterra Laboratory using U.S. Environmental Protection Agency method 525.2. Reporting limits are in micrograms per liter]

\begin{tabular}{|c|c|c|c|}
\hline Compound & Reporting limit & Compound & Reporting limit \\
\hline Alachlor & 0.1 & Endrin & 0.01 \\
\hline Aldrin & .1 & Heptachlor & .04 \\
\hline Atrazine & .1 & Heptachlor epoxide & .02 \\
\hline Benzo [a]pyrene & .02 & Methoxychlor & .1 \\
\hline gamma-BHC (Lindane) & .02 & Metolachlor & .1 \\
\hline Butachlor & .1 & Metribuzin & .1 \\
\hline Dieldrin & .1 & Propachlor & .1 \\
\hline Di (2-ethylhexyl) adipate & .6 & Simazine & .07 \\
\hline Di(2-ethylhexyl) phthalate & .6 & & \\
\hline
\end{tabular}

